\title{
Chronic Depolarization Prevents Programmed Death of Sympathetic Neurons in vitro but Does Not Support Growth: Requirement for $\mathrm{Ca}^{2+}$ Influx but Not Trk Activation
}

\author{
James L. Franklin, Cesar Sanz-Rodriguez, a Anna Juhasz, ${ }^{b}$ Thomas L. Deckwerth, and Eugene M. Johnson, Jr. \\ Department of Molecular Biology and Pharmacology, Washington University School of Medicine, St. Louis, Missouri 63110
}

Continuous exposure of many types of neurons in cell culture to elevated concentrations of $\mathrm{K}^{+}$greatly enhances their survival. This effect has been reported to be mediated by a sustained rise of cytoplasmic free $\mathrm{Ca}^{2+}$ concentration caused by influx of $\mathrm{Ca}^{2+}$ through voltage-gated channels activated by $\mathrm{K}^{+}$-induced chronic depolarization. In this report we investigate the effects of elevated $\mathrm{K}^{+}$on the programmed death that embryonic rat sympathetic neurons undergo in culture when deprived of NGF. Elevated $K^{+}$in the culture medium did not significantly prevent death of NGF-deprived cells until after the third day following plating of embryonic day 21 neurons. On the fifth day after plating, incrementally increasing $\mathrm{K}^{+}$concentrations in the culture medium from 5 to $\mathbf{1 0 0} \mathrm{mm}$ caused chronic depolarization of neurons and had a biphasic effect on survival of NGF-deprived cells. Enhanced survival was steeply related to membrane potential, increasing from no enhanced survival in cells held at potentials between -51 and $-34 \mathrm{mV}$ to $90-100 \%$ of control survival at about $-21 \mathrm{mV}$. At potentials positive to $-21 \mathrm{mV}$, survival decreased. Associated with the chronic depolarization was a sustained rise of steady-state free $\mathrm{Ca}^{2+}$ concentration that showed a biphasic relationship to membrane potential roughly similar to that exhibited by survival. Steadystate $\mathrm{Ca}^{2+}$ concentration increased with increasingly lower membrane potentials to a peak at about $-\mathbf{2 3} \mathrm{mV}$ (to $\approx \mathbf{2 4 0}$ $\mathrm{nm}$ from $\approx \mathbf{4 0} \mathrm{nM}$ at about $-51 \mathrm{mV}$ ) and then decreased at more positive potentials. The elevation of intracellular $\mathrm{Ca}^{2+}$ was largely blocked by dihydropyridine and phenylalkylamine $\mathrm{Ca}^{2+}$ channel antagonists and was potentiated by a dihydropyridine $\mathrm{Ca}^{2+}$ channel agonist. Neither the rise of $\mathrm{Ca}^{2+}$, or survival was affected by the $\mathrm{Ca}^{2+}$ channel antagonist, $\omega$-conotoxin. Therefore, the $\mathrm{Ca}^{2+}$ elevation was probably caused by $\mathrm{Ca}^{2+}$ influx through L-type, but not $\mathrm{N}$-type, chan-

\footnotetext{
Received Dec. 20, 1993; revised May 20, 1994; accepted June 29, 1994.

We thank Ms. Jenny Colombo for technical assistance, Dr. Steven Rothman for providing $\mathrm{Ca}^{2+}$ measurement equipment, Dr. Brenda Shivers of Parke-Davis for the gift of $\omega$-conotoxin, and Dr. William Mobley of the University of California at San Francisco for providing the Trk antibody. Drs. Douglas Creedon, Steven Estus, David Fickbohm, Alan Willard, and Ms. Patricia Osborne provided helpful criticisms of the manuscript. This work was supported by grants from the Ronald McDonald Foundation (E.M.J.) and Amgen (J.I.F.).

Correspondence should be addressed to James L. Franklin, Department of Molecular Biology and Pharmacology, Washington University School of Medicine, Box 8103, 660 South Euclid Avenue, St. Louis, MO 63110.

aresent address: Facultad de Medicina, Universidad de Alcalá de Henares, Campus Universitario, 28871 Alcalá de Henares, Madrid, Spain.

b Present address: Department of Neurology and Psychiatry, Box 397, University of Szeged, Szeged, Hungary H-6701.

Copyright (C) 1995 Society for Neuroscience $0270-6474 / 95 / 150643-22 \$ 05.00 / 0$
}

nels. Antagonists of $L$ channels blocked both survival and the sustained increase of steady-state free $\mathrm{Ca}^{2+}$ at similar concentrations, suggesting that the relevant factor determining survival of depolarized cells was $\mathrm{Ca}^{2+}$ influx rather than some other effect of depolarization. Surprisingly, however, there was no clear correlation between the sustained rise of $\mathrm{Ca}^{2+}$ and survival. Some membrane potentlals that induced similar increases of $\mathrm{Ca}^{2+}$ concentration produced widely different levels of survival. While chronic depolarization promoted survival of neurons in the absence of NGF, cells supported in this manner showed little growth as measured by neurite extension, total cellular protein, and mean somal diameter.

Compounds commonly used as calmodulin antagonists blocked survival of depolarized cells at concentrations that did not affect survival of cells maintained in NGF. However, these antagonists appeared to block survival by inhibiting $\mathrm{Ca}^{2+}$ influx rather than through an effect on calmodulin. Exposure to NGF, but not depolarization without NGF, caused activation of the tyrosine kinase activity of Trk, suggesting that depolarization does not promote survival by activating Trk. Both NGF and depolarization caused tyrosine phosphorylation of a protein with a molecular weight of about 44 kDa that may be an extracellular signal-regulated protein kinase (ERK).

These data show that increased $\mathrm{Ca}^{2+}$ influx induced by chronic depolarization can substitute for trophic factors in promoting survival of sympathetic neurons that would otherwise undergo programmed death. The data also demonstrate that the relationship between intracellular $\mathrm{Ca}^{2+}$ concentration and survival in depolarized neurons is not as straightforward as previously supposed. Additionally, these results suggest that $\mathrm{Ca}^{2+}$ may promote neuronal survival by activating tyrosine kinases downstream from receptor tyrosine kinases and that the signal transduction pathways for growth and survival are separate.

IKey words: programmed cell death, NGF, neuronal calcium, apoptosis, tyrosine kinases, Trk]

Massive cell death occurs as a part of the normal development of the vertebrate nervous system (Oppenheim, 1991). Depending on the neuronal population, approximately $20-80 \%$ of the neurons produced during neurogenesis die before or shortly after birth. A primary purpose of this death is thought to be attainment of an appropriate match between the amount of innervation of a neuronal target and the target size. Availability of neurotrophic substances provided by target and other tissues 
appears to be a major determinant of which cells survive this developmental period. Those neurons receiving a sufficient quantity of trophic factor live while those that do not die. Such developmental death is physiologically appropriate and is called programmed cell death (PCD) to distinguish it from inappropriate death caused by pathological processes. An extensively studied neuronal PCD is that occurring in rat sympathetic neurons deprived of ncurotrophic support. These cells require continued presence of NGF to survive both in vivo and in vitro. When deprived of NGF, sympathetic neurons undergo PCD characterized by atrophy, neurite fragmentation, condensation of chromatin, and degradation of DNA into oligonucleosomal fragments (Martin et al., 1988; Edwards et al., 1991; Deckwerth and Johnson, 1993). The PCD of these neurons also requires macromolecular synthesis, suggesting that the death may be active process in which proteins are synthesized that are responsible for killing the cells (Martin et al., 1988, 1992). These characteristics identify the PCD of these neurons as a form of death known as apoptosis that occurs in many types of cells during embryogenesis, metamorphosis, and tissue turnover (Duvall and Wyllie, 1986).

While neurotrophic factors are major determinants of neuronal survival during the period of $\mathrm{PCD}$, other factors also make important contributions. Electrical activity is thought to bc onc of these factors (Franklin and Johnson, 1992; Schmidt and Kater, 1993). This is suggested by experiments showing that removal of afferent input or pharmacological blockade of electrical activity or neurotransmission causes the death of some types of developing neurons (Lipton, 1986; Maderdrut et al., 1988; Ruitjer et al., 1991; Catsicas et al., 1992; Galli-Resta et al., 1993). In 1970, Scott and Fisher showed that maintaining chicken dorsal root ganglion neurons in cell culture in medium containing elevated concentrations of $\mathrm{K}^{+}$greatly enhances their survival. Since that time, high extracellular $\mathrm{K}^{+}$concentration $\left(\left[\mathrm{K}^{+}\right]_{o}\right)$ has been found to promote in vitro survival of many other types of developing neurons (Scott, 1971, 1980; Nishi and Berg, 1981; Collins and Lile, 1989; Koike et al., 1989; Eichler et al., 1992; for review, see Franklin and Johnson, 1992). Increased $\left[\mathrm{K}^{+}\right]_{0}$ appears to enhance survival by causing a chronic depolarization of cells that may promote survival by mimicking effects of naturally occurring electrical activity. Sustained depolarization apparently induces prolonged activation of voltagegated $\mathrm{Ca}^{2+}$ channels (Nishi and Berg, 1981; Collins and Lile, 1989; Koike et al., 1989). Influx of $\mathrm{Ca}^{2+}$ through these channels has been reported to cause a sustained increase of intracellular free $\mathrm{Ca}^{2+}$ concentration $\left(\left[\mathrm{Ca}^{2+}\right]_{i}\right)$ that is thought to mediate the effects of the depolarization on survival (Collins et al., 1991; Koike and Tanaka, 1991). The mechanisms by which increased $\mathrm{Ca}^{2+}$ influx prevents PCD are not known. In this report we analyze the effect of elevated $\left[\mathrm{K}^{+}\right]_{0}$ on the membrane potential $\left(V_{m}\right)$, survival, $\left[\mathrm{Ca}^{2+}\right]_{i}$, and growth of NGF-deprived rat sympathetic neurons. Additionally, we begin to address the question of how depolarization and $\mathrm{Ca}^{2+}$ influx prevents $\mathrm{PCD}$, investigating a possible role for calmodulin and tyrosine kinases.

Some of these results were reported in abstracts (Franklin et al., 1992, 1993).

\section{Materials and Methods}

Cell culture. Sympathetic neurons were dissociated from superior cervical ganglia (SCG) of Sprague-Dawley (Harlan) rat fetuses on embryonic day 21 (E21) and maintained in cell culture by a modification of the method of Johnson and Argiro (1983). Briefly, after dissection gan- glia were treated at $35^{\circ} \mathrm{C}$ for $30-60 \mathrm{~min}$ with collagenase $(1 \mathrm{mg} / \mathrm{ml})$ or 30 min with collagenase followed by 30 min with trypsin $(2.5 \mathrm{mg} / \mathrm{ml})$ in L-15 medium. The latter method of dissociation was used to obtain cells for most experiments because it yielded more neurons. After enzymatic treatment, ganglia were triturated and debris was separated from dissociated cells by filtration through a size 3-20/14 Nitex filter (Tetko). Deviations from this method are indicated. Cells were plated on air-dried ammoniated collagen in two-well glass chamber slides (Nunc, Inc.) for cell survival assays, $35 \mathrm{~mm}$ plastic tissue culture dishes (Corning or Falcon) for electrophysiology experiments, and, for $\left[\mathrm{Ca}^{2+}\right]_{i}$ measurements, glass coverslips glued with silicon adhesive over holes cut in the bottom of $35 \mathrm{~mm}$ culture dishes. For measurements of neurite outgrowth, neurons were plated at one end of a thin strip of air-dried ammoniated collagen $(\approx 1 \mathrm{~mm}$ diameter and $10-15 \mathrm{~mm}$ long) applied with a P20 pipetman to the bottom of $35 \mathrm{~mm}$ culture dishes or 24 well plates (Costar). Five thousand cells were plated per condition, resulting in 1000-2000 neurons in $9 \mathrm{~d}$ old control cultures. The standard culture medium consisted of Eagle medium with Earle's modified salts supplemented with $10 \%$ fetal bovine serum, $100 \mu \mathrm{g} / \mathrm{ml}$ penicillin, $100 \mu \mathrm{g} / \mathrm{ml}$ streptomycin, $20 \mu \mathrm{M}$ fluorodeoxyuridine, $20 \mu \mathrm{M}$ uridine, $1.4 \mathrm{~mm}$ L-glutamine, and $50 \mathrm{ng} / \mathrm{ml} 2.5 \mathrm{~S} \mathrm{NGF}$ (from mouse submaxillary gland). In one series of experiments (see Fig. 14) the medium was also supplemented with $3.3 \mu \mathrm{g} / \mathrm{ml}$ aphidicolin. For experiments involving chronic depolarization by elevated $\left[\mathrm{K}^{+}\right]_{o}, \mathrm{NaCl}$ in the culture medium was replaced with equimolar amounts of $\mathrm{KCl}$ to maintain osmolarity. Atomic absorption spectrophotometry showed that $\mathrm{K}^{+}$concentration in the culture medium was within $2 \mathrm{~mm}$ of the desired concentration in all instances. For experiments involving elevated extracellular $\mathrm{Ca}^{2+}$ concentration $\left(\left[\mathrm{Ca}^{2+}\right]_{0}\right), \mathrm{NaH}_{2} \mathrm{PO}_{4}$ concentration in the culture medium was lowered 10 -fold (to $14 \mathrm{mg} /$ liter) to prevent precipitation of $\mathrm{Ca}^{2+}$ salts and $\mathrm{NaCl}$ was replaced by $\mathrm{CaCl}_{2}$ in equimolar amounts. This treatment did not alter the $\mathrm{pII}$ of the medium and had no apparent adverse effects on neurons. Details of this method will be reported elsewhere (P. A. Lampe, E. B. Cornbrooks, A. Juhasz, E. M. Johnson, Jr., and J. L. Franklin, unpublished observations). Cultures were maintained in 0.5$2 \mathrm{ml}$ of medium depending on the size of the culture dish. Cultures were deprived of NGF by incubating in medium with no added NGF and an excess of an NGF-neutralizing antibody (an anti-mouse NGF antibody raised in goat).

Cell survival and protein assays. For assay of survival neurons were fixed with $4 \%$ paraformaldehyde and were stained for Nissl substances with crystal violet (EM Diagnostic Systems, Inc.). Cells were then destained with water, dehydrated with ethanol, and transferred to toluene. Coverslips were mounted on the slides with a toluene-based medium (Pro-Texx mounting medium, Baxter Diagnostics) and the slides were codcd for blinded cell counting. All neurons on each slide were counted and each experiment was counted by a single person. Neurons were easily recognized because of their rounded morphology, extensive neurites, and dense Nissl staining. Non-neuronal cells showed little or no Nissl staining. Neurons were scored as viable at the time of fixation if they had well-defined cellular outlines and stained strongly for Nissl substances (see Fig. $2 A$ ). Dead neurons disintegrated into fragments that remained as amorphous debris in the culture dish. These fragments consisted of small enucleate remnants of neurons that could not be confused with intact cells. A few neurons that did not clearly fragment were considered dead because of loss of neurites, massive atrophy, loss of Nissl staining, and lack of an obvious nucleus. Deckwerth and Johnson (1993) have done a detailed temporal analysis of various morphological and biochemical changes occurring in rat SCG neurons in culture after NGF deprivation. They report that the time course of loss of Nissl stained neurons after NGF deprivation corresponds relatively closely to loss of the ability of cultures to reduce the tetrazolium dye 1-(4,5dimethylthiozol-2yl)-2,5-diphenyltetrazolium bromide (MTT), a commonly used measure of cellular viability (Mosmann, 1983). However, they also report that MTT reduction can be affected by metabolic state in viable cells. Since some of the treatments used in this report might alter metabolic rate, MTT reduction was not used as a measure of survival. Several other possible indicators of neuronal viability including 2-deoxyglucose uptake, protein synthesis, RNA synthesis, and cytochrome oxidase activity all decreased after NGF deprivation, but over very different time courses than loss of MTT reduction and Nissl staining. Deckwerth and Johnson also report that the time course of loss of the ability of NGF to promote survival (and hypertrophy) when added to NGF-deprived culturcs corresponds quite closely to loss of Nissl staining. Taken together, these data suggested to us that the best avail- 
able assay for determining viability of these neurons was counting of Nissl stained cells. All survival experiments were performed first on neurons maintained in 24 well plastic tissue culture dishes before cells were plated on chamber slides for quantification of results. By visual inspection all screening experiments had outcomes similar to those obtained by cell counting. Non-neuronal cells were quantified by blinded counting. Cells were scored as non-neuronal based on their morphology (see text). Total protein content was determined by the BCA method with a kit from Pierce.

Electrophysiology. The tight-seal whole-cell recording technique was used to measure $V_{m}$ (Hamill et al., 1981). Patch pipettes were pulled from Kimax-51 glass capillary tubing (Fisher) and their tips were fire polished to a diameter that gave resistances between 1-2 M $\Omega$ when filled with recording solutions. A Dagan 8900 patch-clamp amplifier in current-clamp mode was used to measure $V_{m}$. Neurons were maintained at $35^{\circ} \mathrm{C}$ with a heated stage and viewed with phase-contrast optics on an inverted microscope (Nikon Diaphot). Control cultures were bathed in a solution containing $140 \mathrm{mM} \mathrm{NaCl}, 5 \mathrm{~mm} \mathrm{KCl}, 2 \mathrm{~mm} \mathrm{MgCl}_{2}, 1.8$ $\mathrm{mm} \mathrm{CaCl}_{2}, 5 \mathrm{~mm}$ glucose, and $5 \mathrm{~mm}$ HEPES-Na ${ }^{+}$-HEPES (pH 7.4). For experiments in which $\left[\mathrm{K}^{+}\right]$, was increased in the bathing medium, $\mathrm{KCl}$ replaced $\mathrm{NaCl}$ in equimolar amounts. Pipette solution contained 150 $\mathrm{mm} \mathrm{KCl}, 2 \mathrm{~mm} \mathrm{MgCl}$, $1 \mathrm{~mm}$ ATP, $1 \mathrm{~mm}$ EGTA-NaOH, and $5 \mathrm{~mm}$ HEPF.-Na+-HEPES (pH 7.4).

Measurement of $\left./ \mathrm{Ca}^{2+}\right]_{\mathrm{i}}$. Cultures were prepared for $\left[\mathrm{Ca}^{2+}\right]_{i}$ measurements by incubating them for $45-60 \mathrm{~min}$ at $35^{\circ} \mathrm{C}$ in culture medium appropriate for the experiment and containing the acetomethoxy ester of the $\mathrm{Ca}^{2+}$-sensitive dye fura- $2(6 \mu \mathrm{M}$ in $0.6 \%$ dimethyl sulfoxide; Molecular Probes; Grynkiewicz et al., 1985). After neurons were loaded with fura-2, cullures were rinsed several times with the same medium (equilibrated with $5 \% \mathrm{CO}_{2}$ at $35^{\circ} \mathrm{C}$ in an incubator) without fura-2. The culture dishes were then filled with this medium, dead-air space was eliminated, and lids were sealed onto the dishes with vacuum grease. Cultures were placed on the heated stage of an inverted microscope and viewed through a $40 \times$ oil immersion objective (CF Fluor, 1.30 N.A.). Measurements were made at $35^{\circ} \mathrm{C}$. This method allowed measurement of $\left[\mathrm{Ca}^{2+}\right]_{i}$ under the same conditions (temperature, $\mathrm{pH}$, ionic composition, etc.) in which the neurons had been maintained in culture. Deviations from this method, done in some early experiments, are indicated.

A $75 \mathrm{~W}$ xenon-arc lamp and an optical chopper provided alternating excitation at wavelengths of $340 \pm 10 \mathrm{~nm}$ and $380 \pm 10 \mathrm{~nm}$. A Nikon P1 photomultiplier with a Hammamatsu R 104 photodiode was used to measure intensity of light emitted at $515-560 \mathrm{~nm}$. The emitted light was restricted to that coming from the soma of single cells by an adjustable aperture in the light path. The output of the photomultiplier was filtered at $100 \mathrm{~Hz}$, digitized by an analog to digital converter (Modular Instruments, Inc.), and collected by a specially written computer program that was also used to control the optical chopper and a shutter which allowed light to pass only during the sampling period. Each $340 /$ 380 measurement was made over a period of $1 \mathrm{sec}$. In early experiments four or five different determinations of $\left[\mathrm{Ca}^{2+}\right]_{i}$ taken over a $10-12 \mathrm{sec}$ period for each neuron were averaged. Little variation of $\left[\mathrm{Ca}^{2+}\right]_{i} \mathrm{oc}-$ curred in single neurons over this period; therefore, to expedite measurcment of $\left[\mathrm{Ca}^{2+}\right]_{i}$ in many neurons, a single measurement per cell was made in later experiments. All measurements were corrected for background fluorescence by subtracting the 515-560 emission intensity of the collagen substrate when it was excited at wavelengths of 340 and $380 \mathrm{~nm}$ from that of cells excited at 340 and $380 \mathrm{~nm}$.

Calibration. "In situ" methods (McCormack and Cobbold, 1991) for calibrating fura-2 $340 / 380$ ratios to $\left[\mathrm{Ca}^{2+}\right]_{i}$ proved inadequate. The standard method for obtaining this type of calibration is to treat dyeloaded cells with $\mathrm{Ca}^{2+}$ ionophores in the presence or absence of extracellular $\mathrm{Ca}^{2+}$ to obtain $340 / 380$ ratios with fura- 2 maximally and minimally saturated with $\mathrm{Ca}^{2+}$. In combination with the $K_{d}$ of fura-2 and the ratio of the fluorescence intensities of cells measured in maximally and minimally saturating $\left[\mathrm{Ca}^{2+}\right]_{i}$ at an excitation wavelength of 380 $\mathrm{nm}$, these values are used in Equation 5 of Grynkiewicz et al. (1985) to estimate $\left[\mathrm{Ca}^{2+}\right]_{i}$. We found considerable variation in ratios measured from different cells when the ionophore ionomycin was used. This was especially true with, presumably, saturating $\left[\mathrm{Ca}^{2+}\right]_{i}$, perhaps because of dye leakage or differences in the ability of individual neurons to regulate $\mathrm{Ca}^{2+}$ challenges. Since measurements from many cells over a protracted period were necessary, we considered it essential to utilize a method of calibration that was independent of the properties of the cells and that would reveal artifacts caused by changes in the measuring equipment.
For these reasons, "in situ" calibrations were not done. We chose, instead, to estimate $\left[\mathrm{Ca}^{2+}\right]_{i}$ from standard curves generated by determining fura-2 $340 / 380$ ratios in buffers containing known concentrations of $\mathrm{Ca}^{2+}$. The calibrations were done with a commercially available kit having 11 different buffers containing concentrations of $\mathrm{Ca}^{2+}$ between $0-37.6 \mu \mathrm{M}$ (Molecular Probes). Drops of these buffers containing fura-2 pentapotassium salt $(6 \mu \mathrm{M})$ were placed on glass slides and ratios determined. All fura-2 340/380 ratios recorded from neurons were within the linear portion of these standard curves. The equations derived from linear regression $(R>0.99)$ of these curves were used to estimate $\left[\mathrm{Ca}^{2+}\right]_{i}$. The purpose of these experiments was to determine relative $\left[\mathrm{Ca}^{2+}\right]_{i}$ under different experimental conditions rather than absolute values. Therefore, the values reported herein may vary from the actual $\left[\mathrm{Ca}^{2+}\right]_{i}$ in the cells since the calibration buffers are unlikely to adequately reflect cytoplasmic conditions that may significantly alter fura- 2 characteristics (Grynkiewicz et al., 1985; McCormack and Cobbold, 1991). Although these concentrations should be considered estimates rather than true values, they are shown rather than fura-2 340/380 ratios to facilitate comprehension and allow easier comparisons of our results to those of others who have reported $\left[\mathrm{Ca}^{2+}\right]_{i}$ values in these neurons.

Tyrosine phosphorylation assay. Approximately $10^{6}$ cells were plated on a collagen substrate in $100 \mathrm{~mm}$ tissue culture dishes for each treatment (i.e., lane on a gel). After experiments, cells were rinsed rapidly in ice-cold PBS (pH 7.2) and solubilized at $4^{\circ} \mathrm{C}$ in $0.5 \mathrm{ml}$ of Tris/NP40 lysis buffer containing $10 \mathrm{~mm}$ Tris (pH 6.8), $150 \mathrm{~mm} \mathrm{NaCl}, 5 \mathrm{~mm}$ EDTA, $1 \%$ NP-40, 1 mM sodium orthovanadate, $1 \mathrm{~mm}$ phenylmethylsulfonylfluoride, $10 \mu \mathrm{g} / \mathrm{ml}$ aprotinin, $1 \mu \mathrm{g} / \mathrm{ml}$ pepstatin A, and $5 \mu \mathrm{g} / \mathrm{ml}$ leupeptin. After a $30 \mathrm{~min}$ incubation on ice, the samples were spun in a microcentrifuge for $15 \mathrm{~min}$ at $4^{\circ} \mathrm{C}$ to remove nuclei and cellular debris. To determine the level of Trk tyrosine phosphorylation, lysates were immunoprecipitated for $1 \mathrm{hr}$ at $4^{\circ} \mathrm{C}$ with rabbit antibody $\mathrm{G} 1086$ prepared against a synthetic 15 amino acid peptide corresponding to the C-terminus of human Trk (QALAQAPPVYLDVLG) kindly provided by Dr. William Mobley and colleagues. This sequence is the same as that for all rodent full-length Trk proteins (Zhou et al., 1994). The resulting immunocomplexes were precipitated for $1 \mathrm{hr}$ at $4^{\circ} \mathrm{C}$ with protein A-Sepharose beads (Sigma), separated by SDS-PAGE on $7.5 \%$ gels, transferred to Immobilon-P transfer membrane filters (Millipore), and blotted with anti-phosphotyrosine-specific monoclonal antibody IgG2bk (Upstate Biotechnologies, Inc.). An enhanced-chemiluminescence Western-blotting detection system (Amersham) was used to detect tyrosine-phosphorylated proteins on the membrane. To determine tyrosine phosphorylation of proteins in total cell lysates, proteins were separated, transferred, and blotted in a similar manner. The level of Trk tyrosine phosphorylation was determined by laser densitometry.

Chemicals. Calmidazolium, W7, and $\omega$-conotoxin GVIA were obtained from CalBiochem. $\omega$-Conotoxin MVIIA was a gift from Brenda Shivers at Parke-Davis. Thapsigargin was from L. C. Services. All other chemicals were obtained from Sigma. Chemicals were dissolved in either dimethyl sulfoxide or ethanol, both of which did not affect survival at the concentrations used.

Curve fitting and statistical analysis. Equations were fit to data by using a Marquardt-Levenberg nonlinear least-squares minimization routine (SIGMAPLOT version 5.0, Jandel Scientific). Statistics were done either with SIGMAPLOT or with INSTAT 2 (GraphPad Software). All means are presented \pm SD unless otherwise indicated. The significance of differences was tested with two-tailed Mann-Whitncy $U$ tcsts, $t$ tcsts, or by ANOVA. Differences were considered significant when $p<0.05$.

\section{Results}

Development of $P C D$ suppression by elevated $\left[\mathrm{K}^{+}\right]_{0}$

Withdrawal of NGF from young ( $\approx 1$ week postplating) cultures of embryonic rat SCG neurons causes PCD of most cells within 48-72 hr (Martin et al., 1988; Deckwerth and Johnson, 1993). As these neurons age in vitro (and in vivo) they become increasingly less acutely dependent upon NGF for survival taking much longer to die when deprived of NGF after they have been in culture for several weeks (Lazarus et al., 1976). Therefore, the effects of increased $\left[\mathrm{K}^{+}\right]_{0}$ on PCD was investigated with young cultures of these cells. Previous reports concerning the effects of elevated $\left[\mathrm{K}^{+}\right]_{o}$ on PCD of rat SCG neurons deprived of NGF 

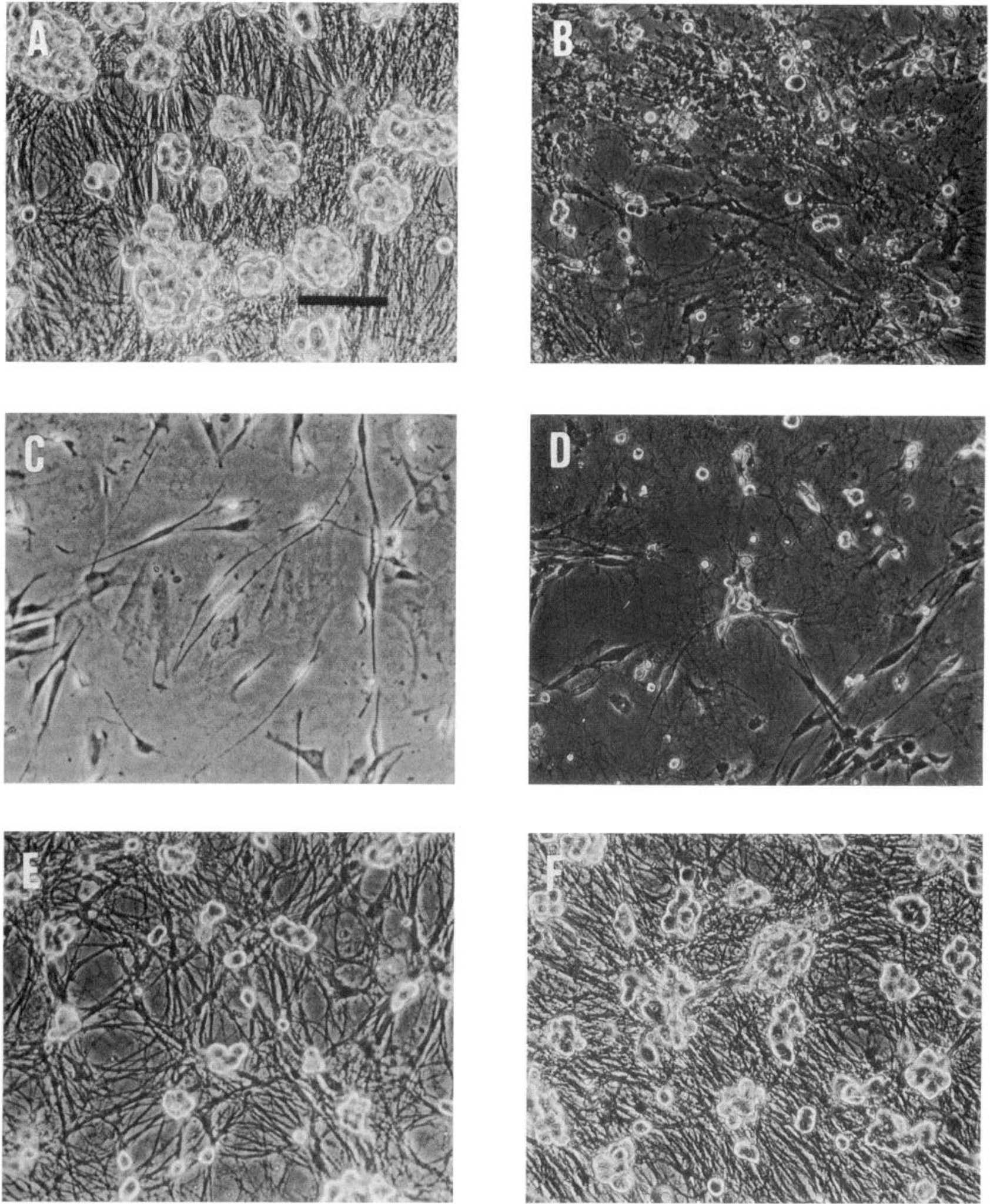

Figure 1. Phase-contrast photomicrographs showing the effects of NGF withdrawal and the ability of elevated [K $\left.{ }^{+}\right]_{o}$ to promote survival of SCG neurons deprived of NGF at different times after plating. $A$, Neurons maintained in the presence of NGF. $B$, Culture maintained in NGF for $5 \mathrm{~d}$ after plating and then deprived of NGF for another $7 \mathrm{~d}$. Extensive somatic atrophy, neurite degeneration, and death have occurred. $C$, Culture in which neurons were plated in medium with $5 \mathrm{~K}$ without NGF. No neurons survived. $D$, Culture in which neurons were plated without NGF in $50 \mathrm{~K}$ medium. Elevated $\left[\mathrm{K}^{+}\right]_{o}$ at the time of plating did not enhance survival; however, $4(E)$ or $6(F) \mathrm{d}$ after plating, 50K medium suppressed PCD caused by NGF deprivation. Photographs were taken $12 \mathrm{~d}$ after plating. Scale bar, $215 \mu \mathrm{m}$.

in cell culture (Martin et al., 1988; Koike et al., 1989; Koike and Tanaka; 1991) have investigated the effects of high $\left[\mathrm{K}^{+}\right]_{o}$ on neurons maintained for the first week after plating in the presence of NGF before they were deprived of NGF and exposed to increased $\left[\mathrm{K}^{+}\right]_{o}$. The influence of elevated $\left[\mathrm{K}^{+}\right]_{o}$ on PCD of younger neurons has not been investigated. Figure 1 illustrates the effect of NGF withdrawal and elevated $\left[\mathrm{K}^{+}\right]_{o}$ on the morphology and survival of SCG neurons during the first week after 

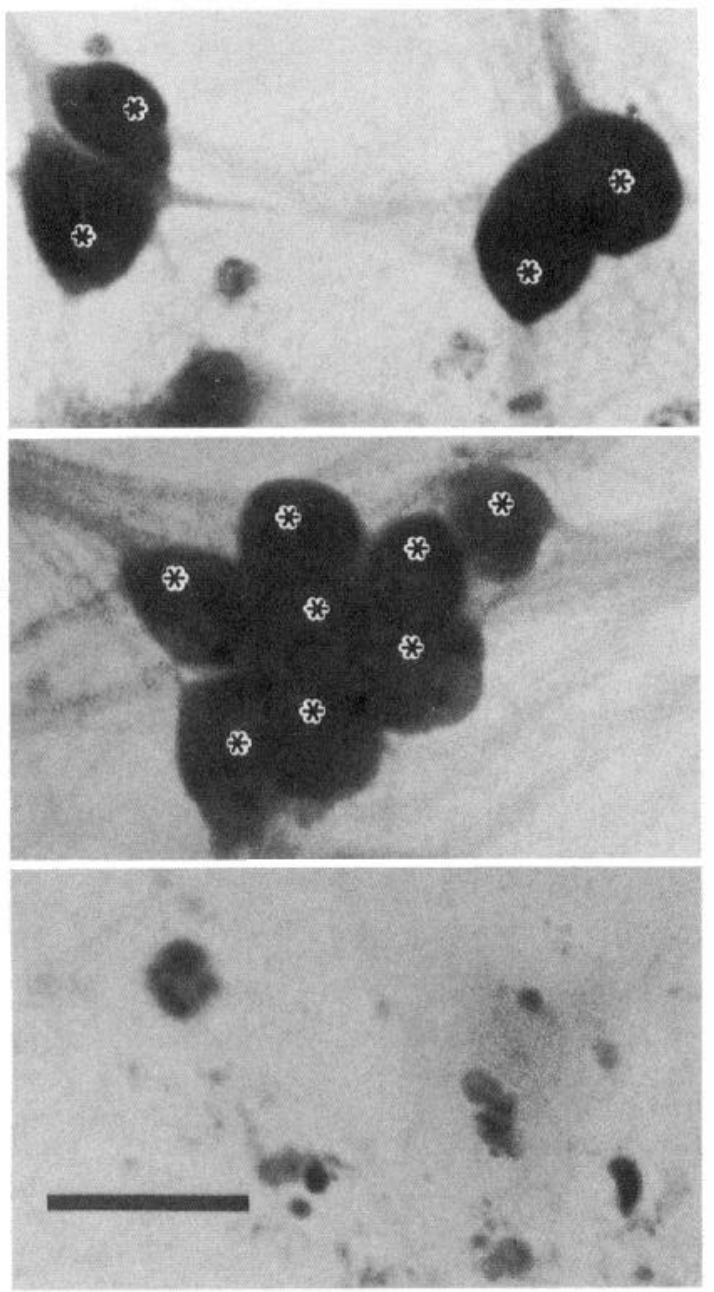

B

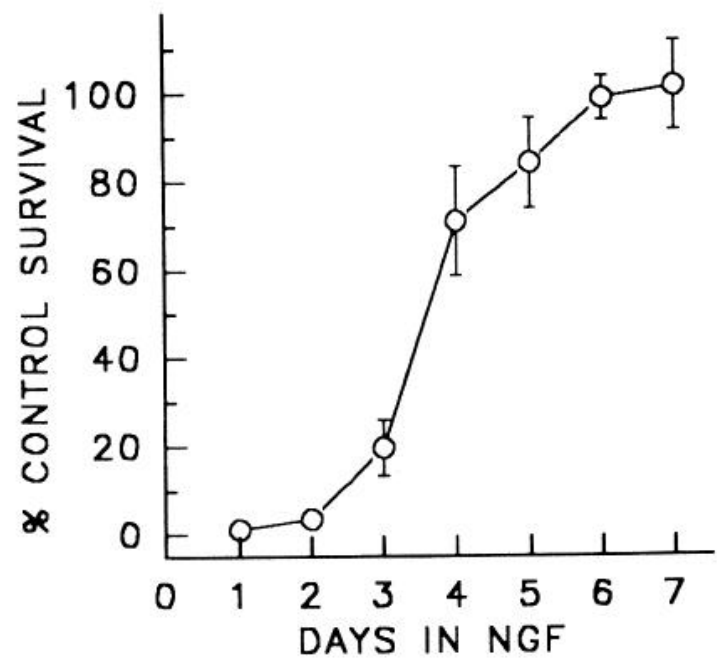

Figure 2. Development of the ability of $50 \mathrm{~K}$ medium to support survival after NGF deprivation. A, Scoring of neuronal survival in Nisslstained neurons. Top to bottom: culture maintained in NGF and $5 \mathrm{~K}$ medium for $9 \mathrm{~d}$ after plating, $9 \mathrm{~d}$ old culture maintained without NGF in $50 \mathrm{~K}$ medium for $4 \mathrm{~d}$, and $9 \mathrm{~d}$ old culture deprived of NGF for $4 \mathrm{~d}$. Note debris from cells that have died in the bottom photograph. Stars indicate cells scored as alive. Scale bar $30 \mu \mathrm{m} . B$, Development of high $\left[\mathrm{K}^{+}\right]_{o}$-promoted survival. Cells were maintained in medium containing $5 \mathrm{~K}$ with NGF for the indicated time before being switched to medium having $50 \mathrm{~K}$ and no NGF. Twelve days after plating, neuronal survival plating. Within $24 \mathrm{hr}$ after dissociation, neurites were visible on neurons maintained in medium with NGF and became extensive during the first week in culture. A small number of nonneuronal cells were visible in cultures. These consisted of broad, flat cells that were probably fibroblasts and spindle-shaped cells that may have been Schwann cells. Neuronal somas supported by NGF were phase bright (Fig. 1A). Withdrawal of NGF caused loss of a phase-bright soma, neurite degeneration, somatic atrophy and fragmentation, and death of most neurons in less than $72 \mathrm{hr}$ (data not shown; Fig. 1B). To determine whether elevated $\left[\mathrm{K}^{+}\right]_{o}$ can prevent PCD during the first week in culture, cells were deprived of NGF at various times after plating and maintained in medium containing $50 \mathrm{~mm} \mathrm{~K}^{+}(50 \mathrm{~K})$. When cells were plated in medium containing $5 \mathrm{~K}$ (normal $\left[\mathrm{K}^{+}\right]_{o}$ ) or $50 \mathrm{~K}$ and no NGF, few neurons survived (Fig. $1 C, D$ ). However, by 4-6 d after plating 50K appeared to support survival of most NGF-deprived neurons (Fig. $1 E, F$ ). The cells supported by elevated $\left[\mathrm{K}^{+}\right]_{o}$ were phase bright and, by inspection, appeared morphologically very similar to cells supported by NGF. Cells in cultures maintained in NGF for $9 \mathrm{~d}$ after plating were 9.04 $\pm 3(N=8)$ non-neuronal while those maintained from the fifth to the ninth day after plating in $50 \mathrm{~K}$ without NGF were 9.27 $\pm 2 \%(N=8)$ non-neuronal. The two values are not significantly different $(p>0.05)$. More neurons survived $4 \mathrm{~d}$ of NGF withdrawal in cultures dissociated with trypsin in addition to collagenase than in those cultures dissociated only with collagenase (see Fig. 6B). Enhanced basal survival in collagenase/trypsindissociated cultures might be because of dissociation of an additional population of neurons that were less acutely dependent upon NGF for survival. Another possibility is that collagenase/ trypsin resulted in a more gentle dissociation than collagenase alone causing less damage to neurons.

The development of the ability of high $\left[\mathrm{K}^{+}\right]_{o}$ to support survival of NGF-deprived cells is quantified in Figure 2. Elevated $\left[\mathrm{K}^{+}\right]_{o}$ did not support survival of NGF-deprived cells during the first $2 \mathrm{~d}$ in culture (survival was $<3 \%$ ). By the third $\mathrm{d}$ after plating, $50 \mathrm{~K}$ medium supported survival of $20 \pm 6 \%$ of NGFdeprived neurons and, by the sixth $\mathrm{d}$ after plating, $50 \mathrm{~K}$ supported survival of $99 \pm 5 \%$ of the cells. Thus, while NGF can suppress PCD at the time of plating, the ability of elevated $\left[\mathrm{K}^{+}\right]_{o}$ to do so develops over a period of several days.

\section{Elevated $\left[\mathrm{K}^{+}\right]_{\mathrm{o}}$ supports survival but not growth}

Campenot (1986) demonstrated that local exposure of the neurites of rat SCG neurons in culture to medium containing $50 \mathrm{~K}$ causes the neurites to degenerate in the presence of NGF while exposure of entire neurons, including neurites, to medium containing $50 \mathrm{~K}$ and NGF allowed continued neurite outgrowth. We confirmed that treatment of entire cells with elevated $\left[\mathrm{K}^{+}\right]_{o}$ did not affect their ability to extend neurites (Fig. $3 A, B$ ). The effects of elevated $\left[\mathrm{K}^{+}\right]_{o}$ on neurite outgrowth of NGF-deprived SCG neurons has not, to our knowledge, been investigated. To determine the effect of high $\left[\mathrm{K}^{+}\right]_{o}$ on neurite growth in the absence of NGF, cells were plated at one end of thin strips of collagen.

was assayed. Survival is shown as percentage of the average number of neurons in cultures maintained for $12 \mathrm{~d}$ after plating in NGF-containing medium. $N=10$ from two separate platings for each data point. Error bars are SD in all figures unless otherwise indicated. Lack of error bars in figures indicates bars smaller than symbols. 

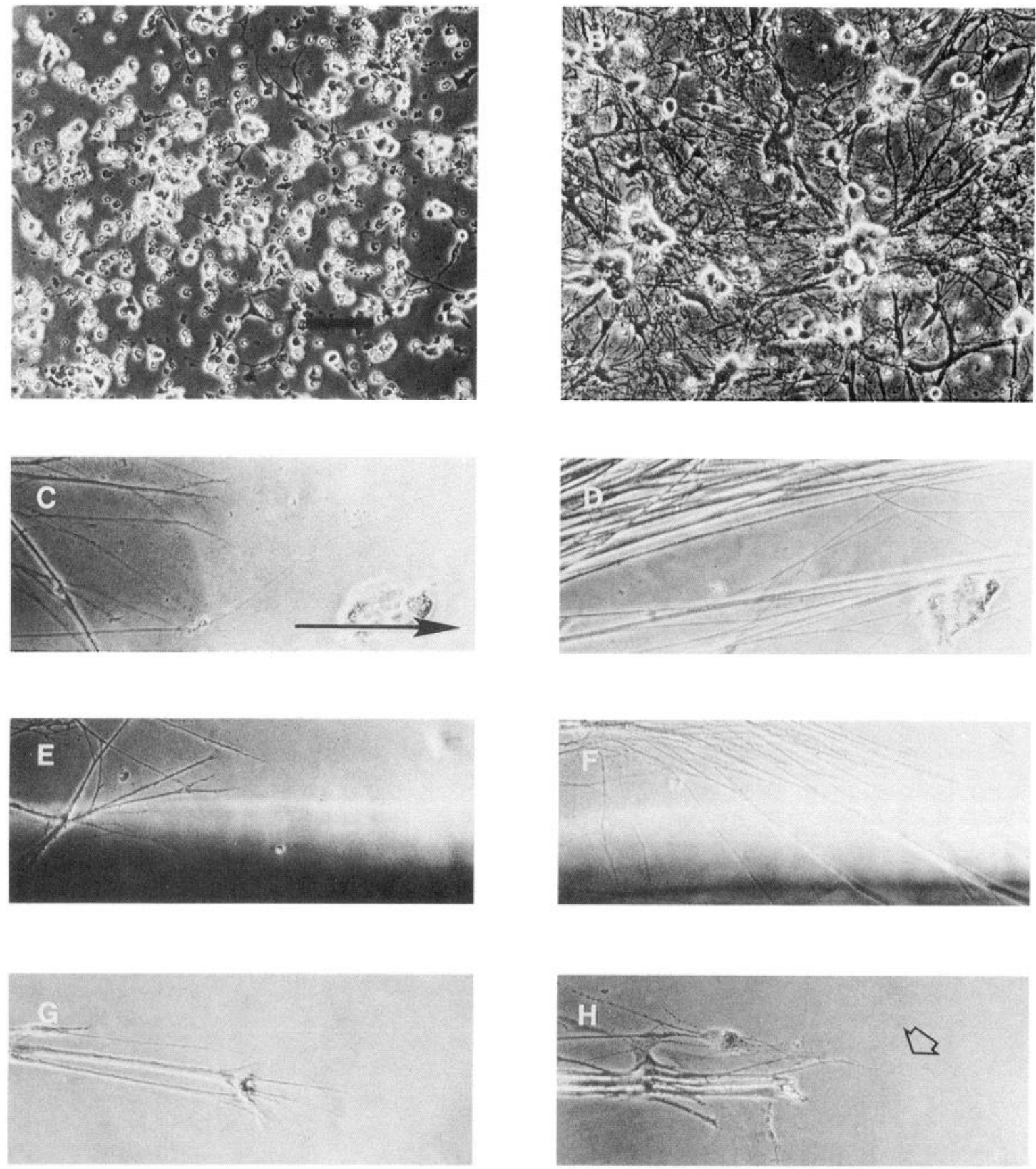

Figure 3. Effects of elevated $\left[\mathrm{K}^{+}\right]_{\rho}$ and NGF on growth. $A$, Photomicrograph of E21 neurons plated for $1 \mathrm{~d}$ in NGF and $50 \mathrm{~K}$. B, Neurons maintained from the time of plating to the 8 th day after plating in NGF and $50 \mathrm{~K}$. Somatic growth and extensive neurite outgrowth has occurred. $C$, Neurites of cells maintained for $6 \mathrm{~d}$ after plating in NGF and $5 \mathrm{~K}$. $D$, The same field of view as in $C$ after cells were maintained in the same medium for 7 additional d. Neurites have grown far out of the field of view. $E$, Neurites of cells maintained for $5 \mathrm{~d}$ after plating in NGF and $5 \mathrm{~K}$ and $1 \mathrm{~d}$ in NGF and $50 \mathrm{~K} . F$. The same field of view as in $E$ after cells were maintained in the same medium for 7 additional days. Again, neurites have grown far out of the field of view. $G$, Neurites of cells maintained $6 \mathrm{~d}$ after plating in NGF and $1 \mathrm{~d}$ in media without NGF and $50 \mathrm{~K}$. $H$, The same field of view after cells were maintained in the same medium for 7 additional days. While some remodeling of neurites occurred, neurite outgrowth was far less extensive than when NGF was present. Note that one process has extended (arrow) for a short distance. The arrow in $C$ shows the general direction of neurite growth along collagen strip. Dark lines in $E$ and $F$ are from a scratch on the bottom of the tissue culture dish that was used to orient the collagen strip. Scale bar, $100 \mu \mathrm{m}$. Scale is the same for $A-H$.

Neurites tended to grow straight along these strips and distance from origin was easily measured. Figure $3 C-F$ shows that neurites continued to grow along these strips when the medium contained NGF and $5 \mathrm{~K}$ or $50 \mathrm{~K}$. However, without NGF neurite outgrowth in the presence of $50 \mathrm{~K}$ was greatly reduced (Fig.
$3 G, H)$. Some neurites grew short distances after the switch to $50 \mathrm{~K}$ without NGF but most did not grow or retracted for short distances. Neurites in these cultures remained firmly attached to the substratum so that lack of attachment to collagen did not account for decreased growth, nor was there any apparent ten- 
A

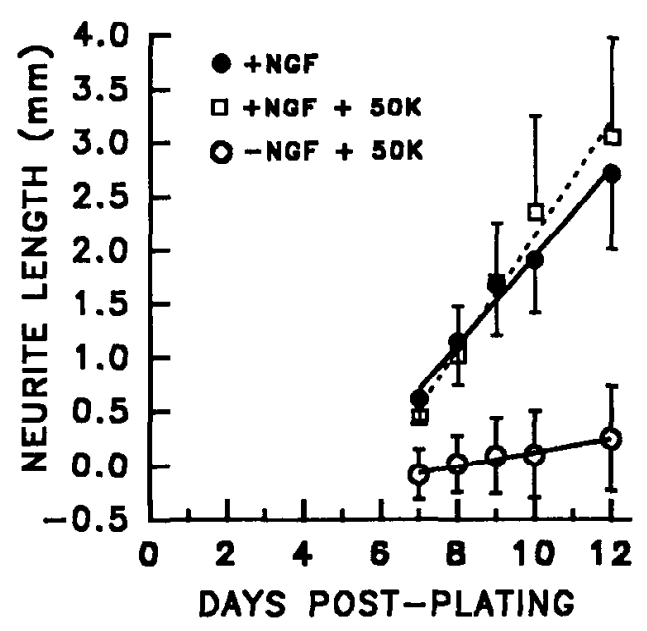

B
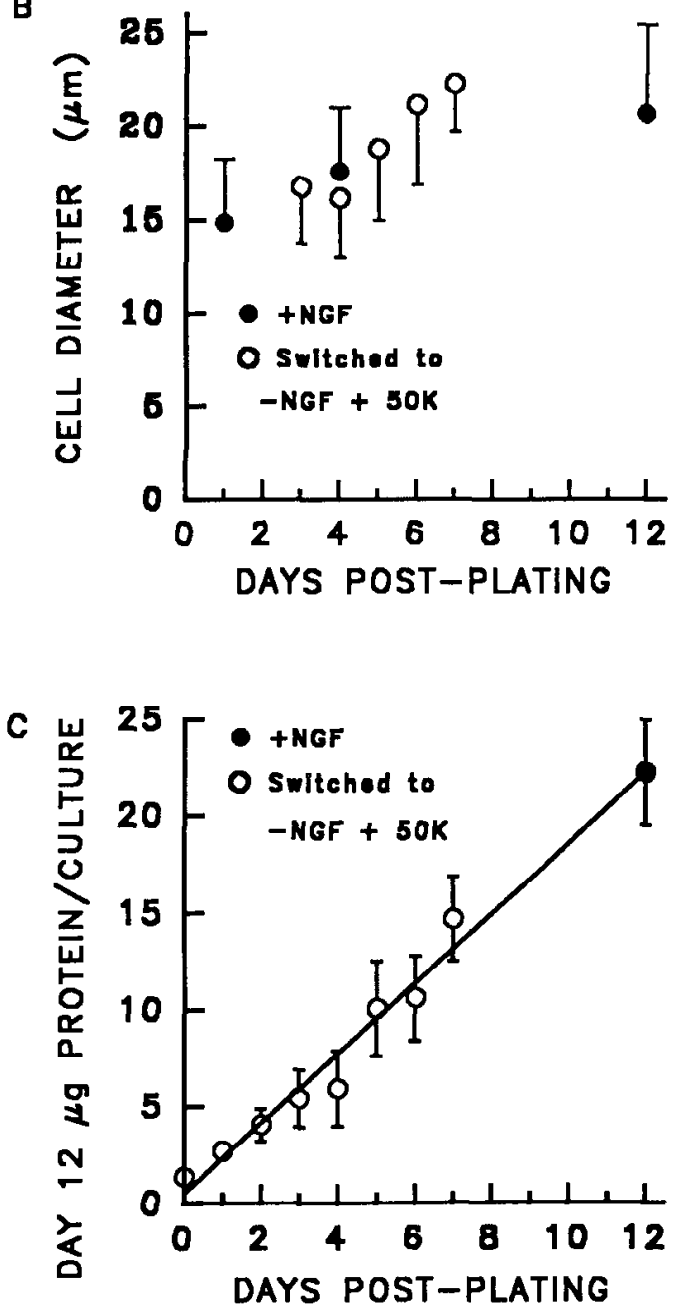

Figure 4. Effects of high $\left[\mathrm{K}^{+}\right]_{0}$ and NGF on growth. $A$, Neurite outgrowth of cells exposed to NGF in $5 \mathrm{~K}$ medium from the time of plating and of cells maintained for the first $5 \mathrm{~d}$ in culture in $5 \mathrm{~K}$ medium and NGF, then switched to medium \pm NGF and containing 50K. Neurites grew at about the same rate in $5 \mathrm{~K}$ or $50 \mathrm{~K}$ when $\mathrm{NGF}$ was present. Neurites of neurons maintained for the first $5 \mathrm{~d}$ in culture in $5 \mathrm{~K}$ medium with $\mathrm{NGF}$, and then switched to an NGF-free medium containing $50 \mathrm{~K}$, grew little. Lines are linear regressions of the three sets of data $(R>$ 0.98 for each). $N=9-22$ from three or four separate platings for each data point. Neurite length is neurite extension beyond the length of dency for neurites to grow back along themselves or on other neurites. Growth of neurites in media containing $5 \mathrm{~K}+\mathrm{NGF}$ and $50 \mathrm{~K} \pm \mathrm{NGF}$ is quantified in Figure $4 A$. Cells were maintained for the first $5 \mathrm{~d}$ in culture in $5 \mathrm{~K}+\mathrm{NGF}$. They were then switched to $50 \mathrm{~K} \pm \mathrm{NGF}$ or continued in $5 \mathrm{~K}+\mathrm{NGF}$. Neurite outgrowth was measured starting on the sixth day after plating. The length of the longest neurites were measured. From the sixth to the twelfth day after plating neurites grew linearly along the collagen strips. The average rate of this growth was about $0.42 \mathrm{~mm} / \mathrm{d}$ when medium contained $\mathrm{NGF}$ and $5 \mathrm{~K}$, a rate that was maintained for at least 2 more weeks (data not shown). Neurons maintained in medium containing 50K and NGF grew at an average rate of about $0.52 \mathrm{~mm} / \mathrm{d}$. Even though cells remained viable in NGF-free medium with $50 \mathrm{~K}$, neuritic growth almost completely ceased. The mean rate of increase in the length of the longest measured neurites in $50 \mathrm{~K}$ medium without NGF was $0.07 \mathrm{~mm} / \mathrm{d}$. Increase of the somal diameter of cells maintained in $50 \mathrm{~K}$ medium without NGF was also inhibited (Fig. $4 B$ ). For example, the average somal diameters of neurons maintained in NGF for $12 \mathrm{~d}$ after plating was $21 \pm 5 \mu \mathrm{m}(N=$ 25), while the somas of neurons maintained in NGF for $4 \mathrm{~d}$ after plating before being deprived of NGF and switched to medium containing $50 \mathrm{~K}$ were $16 \pm 3 \mu \mathrm{m}(N=25)$ on the twelfth day after plating $(p<0.001)$. The average diameter of neurons maintained for the first $4 \mathrm{~d}$ in culture in NGF and $5 \mathrm{~K}$ was 17.6 $\pm 3 \mu \mathrm{m}(N=25)$, not significantly different from cells switched to $50 \mathrm{~K}$ medium without NGF and maintained until the twelfth day after plating in this medium $(p>0.05)$. Therefore, maintenance of cells in $50 \mathrm{~K}$ without NGF does not appear to support growth of cell diameter.

The decreased growth of NGF-deprived neurons maintained in high $\left[\mathrm{K}^{+}\right]_{0}$ was reflected in lower total protein content in these cells than in cells maintained in NGF. Neurons were deprived of NGF and exposed to $50 \mathrm{~K}$ medium at various times after plating. The cells were then maintained in $50 \mathrm{~K}$ without NGF until the twelfth day after plating when protein content was determined (Fig. $4 C$ ). The longer the cells had been in NGF and $5 \mathrm{~K}$ before deprivation and switch to $50 \mathrm{~K}$, the greater the protein content measured on the twelfth day. Total protein content on the twelfth day after plating was a linear function of the amount of time the cells had been exposed to the NGF before deprivation and switch to $50 \mathrm{~K}$ medium. In cultures switched to $50 \mathrm{~K}$ without NGF before the fourth or fifth day after plating, decreased protein content compared to $12 \mathrm{~d}$ control can be accounted for at, least in part, by inability of elevated $\left[\mathrm{K}^{+}\right]_{0}$ to promote survival (i.e., cells died). However, decreased protein in cells switched to $50 \mathrm{~K}$ at later times, when most cells are saved

neurites measured $6 \mathrm{~d}$ after plating. $B$, Cell diameters of neurons maintained in NGF-containing medium with $5 \mathrm{~K}$ before being switched to NGF-free medium containing $50 \mathrm{~K}$ on the indicated days after plating (open circles). Diameter was measured on the twelfth day after plating. Solid circles show diameters of neurons maintained in NGF and $5 \mathrm{~K}$ for 1,4 , and $12 \mathrm{~d}$ from the time of plating. $N=23-25$ from a single plating for each data point. $C$, Total protein content of cultures maintained for the indicated period in NGF-containing medium before being switched to NGF-free medium with $50 \mathrm{~K}$ and then maintained in this medium until the twelfth day after plating when protein content was determined (open circles). Solid circle is the protein content of cultures maintained for $12 \mathrm{~d}$ after plating in NGF and $5 \mathrm{~K}$. Solid line is linear regression of the data $(R>0.99) . N=2$ cultures for day 0 and $3-4$ cultures for each succeeding day. Data is from a single plating. 


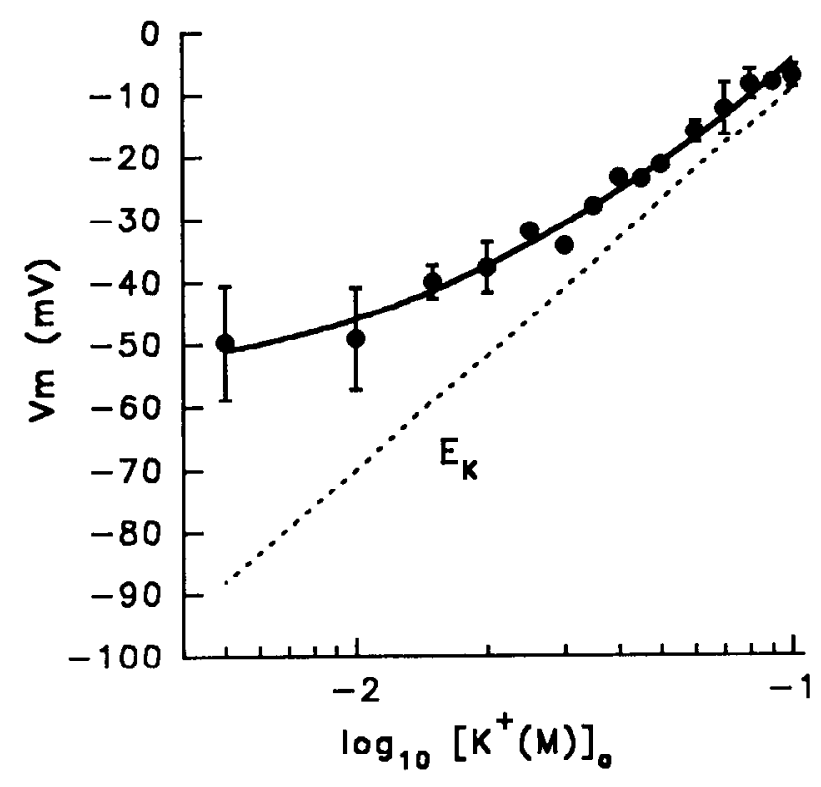

Figure 5. Effect of $\left[\mathrm{K}^{+}\right]_{o}$ on $V_{m}$. Membrane potential was measured in cells exposed to different $\left[\mathrm{K}^{+}\right]_{o}(5-50 \mathrm{mM}$ in $5 \mathrm{~mm}$ increments and $50-100 \mathrm{~mm}$ in $10 \mathrm{~mm}$ increments) for up to $2 \mathrm{hr}$. The solid line is a quadratic regression of the data, and the dotted line represents $E_{\mathrm{K}}$ at $35^{\circ} \mathrm{C}$ calculated from the Nernst equation (Hille, 1992). $N=8$ for $5 \mathrm{~K}$ and 3 for all other data points. Potentials were measured in neurons 5$8 \mathrm{~d}$ after plating.

from death by $50 \mathrm{~K}$, likely reflects decreased growth. For example, cultures of neurons maintained in NGF and $5 \mathrm{~K}$ for 6 day after plating and kept in $50 \mathrm{~K}$ without NGF until the twelfth day after plating had a protein content of $10.6 \pm 2 \mu \mathrm{g}$ protein/ culture while cultures maintained for the entire $12 \mathrm{~d}$ in NGF and $5 \mathrm{~K}$ had a protein content of $22 \pm 3 \mu \mathrm{g}$ protein/well $(p<$ $0.01)$. Taken together, these data indicate that NGF promoted both growth and survival of neurons, while high $\left[\mathrm{K}^{+}\right]_{o}$ promoted survival in the absence of NGF but supported little growth.

\section{Effect of elevated $\left[K^{+}\right]_{\mathrm{o}}$ on $\mathrm{V}_{\mathrm{m}}$}

Elevated $\left[\mathrm{K}^{+}\right]_{o}$ causes chronic depolarization of neurons in culture (Chalazonitis and Fischbach, 1980) and this depolarization, rather than another effect of increased $\left[\mathrm{K}^{+}\right]_{o}$, is thought to enhance survival (Franklin and Johnson, 1992). To detcrmine the membrane potentials $\left(V_{m}\right)$ of rat SCG neurons in varying $\left[\mathrm{K}^{+}\right]_{o}$, we exposed neurons to medium containing 5-100 $\mathrm{mM} \mathrm{K}^{+}$and measured $V_{m}$ by tight-seal whole-cell recording (Hamill et al., 1981). The mean $V_{m}$ of neurons in medium containing $5 \mathrm{~K}$ was $-50 \pm 9 \mathrm{mV}(N=8)$ with a range of -39 to $-64 \mathrm{mV}$. These resting $V_{m}$ values are similar to those reported previously for rat SCG neurons in culture with this recording method (Nerbonne and Gurney, 1989). Exposure of neurons to medium having elevated $\left[\mathrm{K}^{+}\right]_{0}$ caused depolarization as illustrated in Figure 5 . In medium containing $5 \mathrm{~K}$, mean $V_{m}$ was about $40 \mathrm{mV}$ positive to $\mathrm{K}^{+}$equilibrium potential $\left(E_{\mathrm{k}}\right)$, indicating that a substantial fraction of the resting $V_{m}$ in these cells was determined by ions other than $\mathrm{K}^{+}$. The measured $V_{m}$ of neurons maintained in $45 \mathrm{~K}$ medium for $4 \mathrm{~d}$ was not significantly different from that of neurons exposed for less than $2 \mathrm{hr}$ to $45 \mathrm{~K}(-23 \pm 2 \mathrm{mV}, N$ $=4$ and $-24 \pm 0.6 \mathrm{mV}, N=3$, respectively; $p>0.05$ ), indicating that the depolarization was chronic. Three out of eight neurons in medium containing $5 \mathrm{~K}$ fired spontaneous action potentials at a relatively slow rate $(\approx 1$ action potential $/ 5 \mathrm{sec}$, e.g.) and one out of three cells in medium containing $10 \mathrm{~K}$ was spontaneously active. In media having greater than $10 \mathrm{~K}(N=39$ neurons), no electrical activity was evident in any neurons, probably because of voltage-dependent inactivation of ionic channels at more positive $V_{m}$ values. The range of $V_{m}$ values in media with $\mathrm{K}^{+}$ greater than $10 \mathrm{~mm}$ was much narrower than that in medium with $5 \mathrm{~K}$ and the $V_{m}$ values were closer to $E_{\mathrm{K}}$. The decrease in variability of $V_{m}$ with increasing $\left[\mathrm{K}^{+}\right]_{o}$ was probably a reflection of increased $\mathrm{K}^{+}$conductance at more positive $V_{m}$ values which would have the effect of driving $V_{m}$ closer to $E_{\mathrm{K}}$.

The relationship between intracellular and extracellular $\mathrm{K}^{+}$, $\mathrm{Na}^{+}$, and $\mathrm{Cl}^{-}$concentrations and the $V_{m}$ of excitable cells is often modeled with the Croldman-Hodgkin-Katz (GHK) potential equation (Goldman, 1943; Hodgkin and Katz, 1949). However, the data were not adequately fit by this equation or by a modification of the constant field equation (Jan and Jan, 1976) that takes into account the relative permeabilities of all ions $\left(\mathrm{K}^{+}, \mathrm{Na}^{+}, \mathrm{Mg}^{2+}, \mathrm{Ca}^{2+}\right.$, and $\left.\mathrm{Cl}^{-}\right)$in the extracellular and intracellular solutions (not shown). A monotonic relationship between $\left[\mathrm{K}^{+}\right]_{o}$ and $V_{m}$ values could, therefore, not be obtained with the GHK equation or its modifications. To obtain a "smooth" relationship between $\left[\mathrm{K}^{+}\right]_{o}, V_{m}$ values, and $V_{m}$-dependent variables, measured $V_{m}$ values as a function of $\left[\mathrm{K}^{+}\right]_{o}$ were fitted with a smooth curve by quadratic regression. This regression $(R>0.99)$ differed by less than $3 \mathrm{mV}$ from the measured mean $V_{m}$ values in all cases. In media with $5-10 \mathrm{~K}$, the measured $V_{m}$ values of individual cells varied by $5-13 \mathrm{mV}$ from the fitted regression values while, in media with greater than or equal to $15 \mathrm{~K}$, the measured $V_{m}$ values in individual cells was $0-5 \mathrm{mV}$ different from the fitted values. The $V_{m}$ values in the remainder of this report were taken from the regression equation. The values stated imply a range of $V_{m}$ values that at low $\left[\mathrm{K}^{+}\right]_{0}(5-10 \mathrm{~K})$ is rather large and at higher $\left[\mathrm{K}^{+}\right]_{o}$ is rather small.

\section{Effects of varying $\mathrm{V}_{\mathrm{m}}$ on neuronal survival}

Figure $6 \mathrm{~A}$ illustrates that survival of neurons deprived of NGF $5 \mathrm{~d}$ after plating and chronically depolarized for $4 \mathrm{~d}$ was steeply related to $V_{m}$. Potentials negative to $-34 \mathrm{mV}(25 \mathrm{~K})$ did not enhance survival. As mean $V_{m}$ decreased from $-34 \mathrm{mV}$ to -21 $\mathrm{mV}(50 \mathrm{~K})$, mean survival increased from $4 \pm 3 \%$ to $89 \pm 20 \%$ of control. Positive to $-21 \mathrm{mV}$, mean survival decreased steeply with decreasing $V_{m}$, dropping to a minimum of $12 \pm 10 \%$ of control at $-7 \mathrm{mV}(90 \mathrm{~K})$. The decrease in survival at more positive $V_{m}$ values was not the result of a toxic effect of the high $\left[\mathrm{K}^{+}\right]_{o}$ that induced those potentials because neurons maintained in medium containing $70-100 \mathrm{~K}$ remained healthy if NGF was present.

Prevention of PCD by chronic depolarization was long term. Approximately the same percentage of neurons that were depolarized for $10 \mathrm{~d}$ without NGF survived at a particular $V_{m}$ as those depolarized for only $4 \mathrm{~d}$ (Fig. $6 B, C$ ). Mean survival in cultures depolarized for $10 \mathrm{~d}$ without NGF was enhanced as much as $119 \pm 34 \%$ above the survival of NGF-deprived neurons maintained in $5 \mathrm{~K}$ for $10 \mathrm{~d}$. This level of survival was not significantly different from that of control cells maintained for the same period in NGF $(p>0.05)$. Cultures held at $-21 \mathrm{mV}$ for 1-2 months after NGF withdrawal were phase bright and appeared as healthy as cells maintained for the same period in the presence of NGF (not shown). Therefore, once the ability 
A

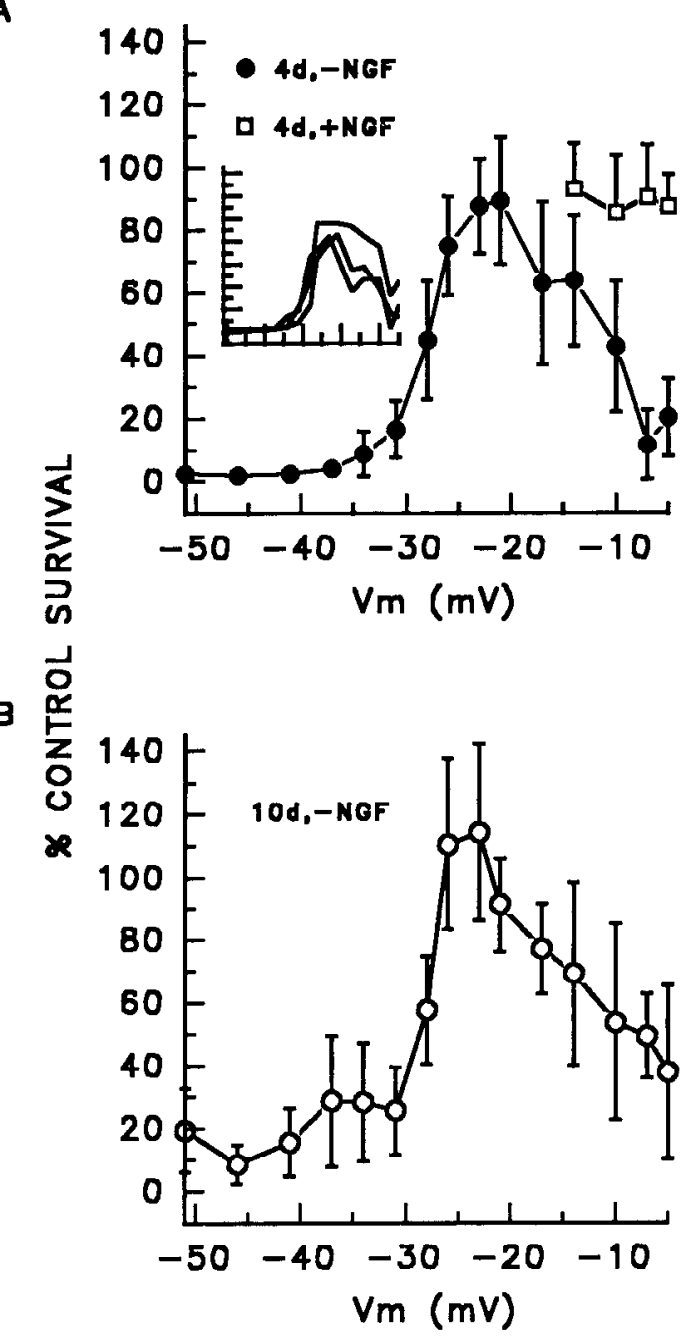

C

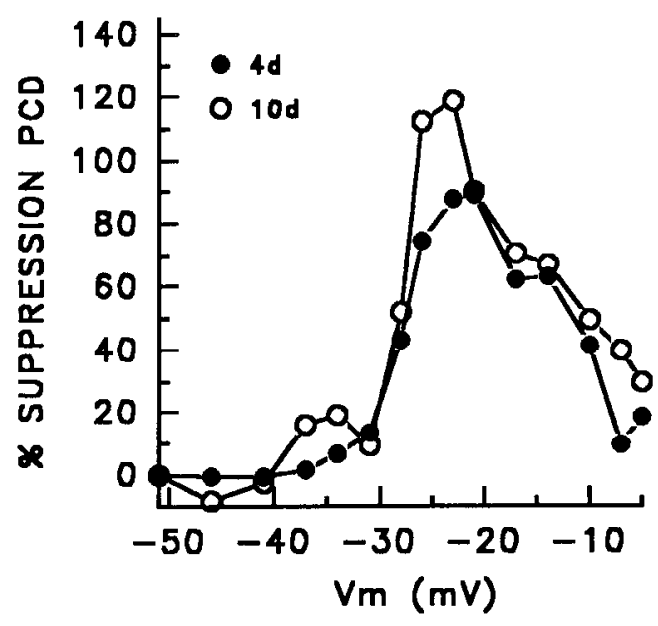

Figure 6. Relationship between $V_{m}$ and survival. $A$, Survival of neurons maintained for $5 \mathrm{~d}$ after plating in medium containing NGF and $5 \mathrm{~K}$ followed by $4 \mathrm{~d}$ in media $\pm \mathrm{NGF}$ and containing various $\left[\mathrm{K}^{+}\right]_{0}$ to

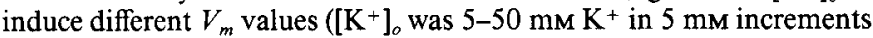
and $50-100 \mathrm{~mm} \mathrm{~K}+$ in $10 \mathrm{~mm}$ increments). Squares show survival of neurons maintained in the presence of NGF for the same period. $N=$ 8-12 from two or three platings for each data point. Inset shows mean survival of each of the three separate platings. Symbols and error bars are omitted in inset for clarity. $B$, Survival of neurons deprived of NGF of chronic depolarization to prevent PCD develops it can permanently substitute for NGF in promoting survival.

Effect of $\mathrm{V}_{\mathrm{m}}$ on $\left[\mathrm{Ca}^{2+}\right]_{\mathrm{i}}$

Thayer et al. (1987) and Tolkovsky et al. (1990) have shown that acute depolarization of rat SCG neurons with elevated $\left[\mathrm{K}^{+}\right]_{o}$ causes a biphasic increase of $\left[\mathrm{Ca}^{2+}\right]_{i}$ consisting of a transient rise of $\left[\mathrm{Ca}^{2+}\right]_{i}$ followed by a sustained increase lasting for at least several tens of minutes. Koike and Tanaka (1991) showed that long periods of exposure to elevated $\left[\mathrm{K}^{+}\right]_{o}$ causes a sustained increase of $\left[\mathrm{Ca}^{2+}\right]_{i}$ in these neurons that can last for several days. We have confirmed and extended these results. Figure $7 A$ illustrates the effect of acute depolarization to $-21 \mathrm{mV}$ with $50 \mathrm{~K}$ on the $\left[\mathrm{Ca}^{2+}\right]_{i}$ of a single SCG neuron. Within $45 \mathrm{sec}$ after initial depolarization, $\left[\mathrm{Ca}^{2+}\right]_{i}$ in this cell rose from a resting concentration of $69 \mathrm{~nm}$ to a peak of $427 \mathrm{nM}$. During the next 5-10 min $\left[\mathrm{Ca}^{2+}\right]_{i}$ fell to a sustained level of $\approx 160 \mathrm{nM}$. Figure $7 B-D$ shows that $\left[\mathrm{Ca}^{2+}\right]_{i}$ remained elevated above baseline with long periods of exposure to high $\left[\mathrm{K}^{+}\right]_{o}$. In neurons held at $-51 \mathrm{mV}$ for $24-$ $27 \mathrm{hr}$, mean $\left[\mathrm{Ca}^{2+}\right]_{i}$ was $43 \pm 13 \mathrm{nM}$. At all $V_{m}$ values positive to $-51 \mathrm{mV}$, mean $\left[\mathrm{Ca}^{2+}\right]_{i}$ was elevated above control levels, increasing with lower $V_{m}$ values to a peak of $239 \pm 69 \mathrm{nM}$ at $-23 \mathrm{mV}(45 \mathrm{~K})$. At $V_{m}$ values lower than $-23 \mathrm{mV},\left[\mathrm{Ca}^{2+}\right]_{i}$ decreased with lower $V_{m}$ values to a minimum of $115 \pm 37 \mathrm{nM}$ at $-7 \mathrm{mV}$. Neurons maintained at depolarized $V_{m}$ values for 4 d (Fig. $7 C$ ) or $11 \mathrm{~d}$ (Fig. $7 D$ ) had mean $\left[\mathrm{Ca}^{2+}\right]_{i}$ substantially elevated above that of cells maintained at $-51 \mathrm{mV}$ for the same period. For example, after $4 \mathrm{~d}$ of depolarization, mean $\left[\mathrm{Ca}^{2+}\right]_{i}$ was $181 \pm 35 \mathrm{nM}$ in neurons held at $-23 \mathrm{mV}$, while at -51 $\mathrm{mV}$ it was $58 \pm 12 \mathrm{nM}$. After $11 \mathrm{~d}$ of depolarization mean $\left[\mathrm{Ca}^{2+}\right]_{i}$ in cells held at $-23 \mathrm{mV}$ had dropped to $139 \pm 38 \mathrm{nM}$, but remained elevated above the resting level of $51 \pm 21 \mathrm{~nm}$ at $-51 \mathrm{mV}$. These data suggest that chronic depolarization of SCG neurons causes continuous $\mathrm{Ca}^{2+}$ influx through voltage-gated channels. The decrease of $\left[\mathrm{Ca}^{2+}\right]_{i}$ at potentials positive to -23 $\mathrm{mV}$ probably reflects increasing voltage-dependent inactivation of $\mathrm{Ca}^{2+}$ channels at more positive Vms.

Even though $V_{m}$ was "clamped" within a relatively narrow range by $\left[\mathrm{K}^{+}\right]_{o}$ greater than or equal to $15 \mathrm{~mm},\left[\mathrm{Ca}^{2+}\right]_{i}$ varied widely from cell to cell at a specific $V_{m}$. This was particularly true of neurons that had been in culture for $6 \mathrm{~d}$ and depolarized for 24-27 hr when $\left[\mathrm{Ca}^{2+}\right]_{i}$ measurements were made. For example, the range of $\left[\mathrm{Ca}^{2+}\right]_{i}$ measured in cells depolarized to -23 $\mathrm{mV}$ for 24-27 hr was 113-406 nM, while the range in cells held at $-23 \mathrm{mV}$ for $4 \mathrm{~d}$ was $98-268 \mathrm{~nm}$, and, for $11 \mathrm{~d}$, the range was 81-177 nM. One possible explanation for such a wide variation

$\longleftarrow$

$5 \mathrm{~d}$ after plating and held at different $V_{m}$ values for $10 \mathrm{~d}$ as in $A$. Survival is similar to that $4 \mathrm{~d}$ after withdrawal. The baseline survival is greater in $B$ than $A$ because cells were dissociated with collagenase and trypsin while those in $A$ were dissociated only with collagenase (see text). Control survival is average number of neurons in sibling cultures (usually four) maintained in NGF and $5 \mathrm{~K}(-51 \mathrm{mV})$ for the same period. $N=6-12$ from three platings for each data point. $C$, Data in $A$ and $B$ normalized to percentage suppression of $\mathrm{PCD}$, defined as

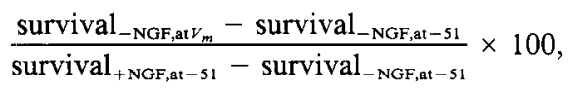

where survival ${ }_{- \text {NGF,at }}$ is survival of cells at a particular $V_{m}$ without $\mathrm{NGF}$, survival ${ }_{+\mathrm{NGF}, \mathrm{at}-51}$ is average survival of control cells in sister cultures with $\mathrm{NGF}$, and survival $-\mathrm{NGF,at-51}$ is average survival of control cells in sister cultures without NGF. 

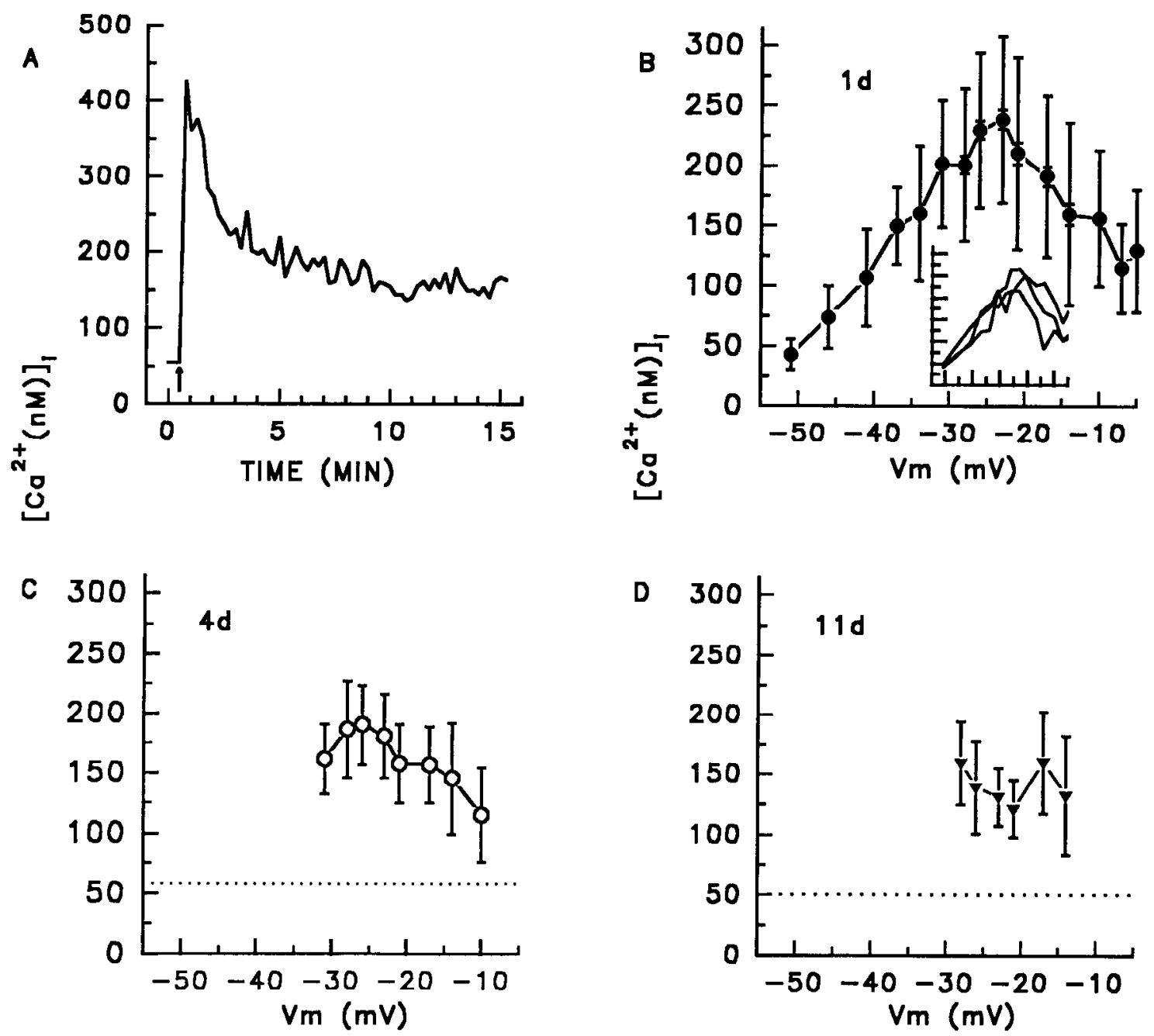

Figure 7. Effect of $V_{m}$ on $\left[\mathrm{Ca}^{2+}\right]_{i} . A$, Representative response of $\left[\mathrm{Ca}^{2+}\right]_{i}$ in a single SCG neuron to acute depolarization to $-21 \mathrm{mV}$ with $50 \mathrm{~K}$.

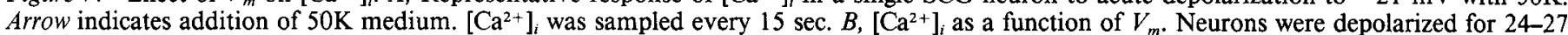
hr before fura-2 measurements of $\left[\mathrm{Ca}^{2+}\right]_{i}$ were made. $N=71-76$ from three separate platings for each data point; inner error bars are SEM. Inset shows mean $\left[\mathrm{Ca}^{2+}\right]_{i}$ of each of the three separate platings. $C$, Effect of $4 \mathrm{~d}$ of depolarization on $\left[\mathrm{Ca}^{2+}\right]_{i} . N=49-75$ from two or three platings for each data point. $D$, Effect of $11 \mathrm{~d}$ of depolarization on $\left[\mathrm{Ca}^{2+}\right]_{i} . N=24-26$ from a single plating for each data point. [Ca $\left.{ }^{2+}\right]_{i}$ in depolarized cells decreased with time in culture but remained substantially elevated above control levels. Dotted lines indicate $\left[\mathrm{Ca}^{2+}\right]$, in neurons held at $-51 \mathrm{mV}$ in the presence of NGF for the same period. Neurons were depolarized to the indicated $V_{m}$ with medium containing elevated $\left[\mathrm{K}^{+}\right]_{o}(5-50$ mM in $10 \mathrm{~mm}$ increments and 50-100 mM in $10 \mathrm{~mm}$ increments) and no NGF, $5 \mathrm{~d}$ after plating. Lack of a full range of $V_{m}$ values at $4 \mathrm{~d}$ and $11 \mathrm{~d}$ indicates dcath of most cells at $V_{m}$ valucs outside of the ranges shown (see Fig. 6).

of $\left[\mathrm{Ca}^{2+}\right]_{i}$ at a particular $V_{m}$ is a measurement artifact caused by the brief time that $\left[\mathrm{Ca}^{2+}\right]_{i}$ was sampled in each cell (see Materials and Methods); that is, longer sampling periods might reveal that $\left[\mathrm{Ca}^{2+}\right]_{i}$ in single neurons is not a true steady state but changes slowly with time. Thus, individual cells might fluctuate through a wide range of $\left[\mathrm{Ca}^{2+}\right]_{i}$ and short sampling periods, which take brief $\left[\mathrm{Ca}^{2+}\right]_{i}$ "snapshots," may not reveal the entire range of $\left[\mathrm{Ca}^{2+}\right]_{i}$ that single cells have over longer periods. To test this possibility, $\left[\mathrm{Ca}^{2+}\right]_{i}$ was measured over a period of 30 $\min$ in six neurons plated for $6 \mathrm{~d}$ and depolarized to $-21 \mathrm{mV}$ for 24-27 hr. Intracellular [ $\mathrm{Ca}^{2+}$ ] in individual cells varied by only $5-35 \mathrm{~nm}$ from the mean value over this period. This range of $\left[\mathrm{Ca}^{2+}\right]_{i}$ was equivalent to the $\left[\mathrm{Ca}^{2+}\right]_{i}$ fluctuations of the acutely depolarized neuron shown in Figure $7 A$ (28 nm maximal) and in other acutely depolarized cells. These small fluctuations appeared random and were probably caused by "noise" in the measuring system rather than actual changes of $\left[\mathrm{Ca}^{2+}\right]_{i}$. Therefore, the measured $\left[\mathrm{Ca}^{2+}\right]_{i}$ in single depolarized neurons re- mained at a steady state with only minor variations from a mean value, and the variation of $\left[\mathrm{Ca}^{2+}\right]_{i}$ between cells was not a sampling artifact. Some of the variation in $\left[\mathrm{Ca}^{2+}\right]_{i}$ between neurons "clamped" at the same $V_{m}$ probably reflected real differences in the $\mathrm{Ca}^{2+}$ homeostatic properties of individual cells. However, part of the variation can probably also be accounted for by fura- 2 artifacts such as differential compartmentalization of nonhydrolyzed fura- 2 ester in different cells or differential fura-2 loading in individual cells. To what degree each of these possibilities contributed to the cell to cell $\left[\mathrm{Ca}^{2+}\right]_{i}$ variations observed was not determined. Even though some neurons fired spontaneous action potentials at $V_{m}$ values negative to about $-41 \mathrm{mV}(15 \mathrm{~K})$, individual cells did not show significant variations of $\left[\mathrm{Ca}^{2+}\right]_{i}$ when held negative to this $V_{m}$. This lack of $\left[\mathrm{Ca}^{2+}\right]_{i}$ change measured in electrically active cells may be because the low rate of electrical activity might not cause a significant global change of $\left[\mathrm{Ca}^{2+}\right]_{i}$ that could be measured by the techniques used here. The slow sampling rate used might also 
A

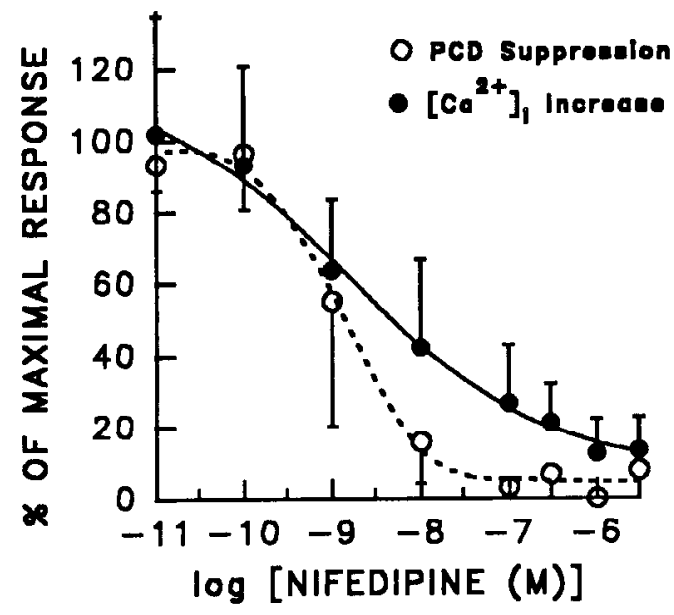

B

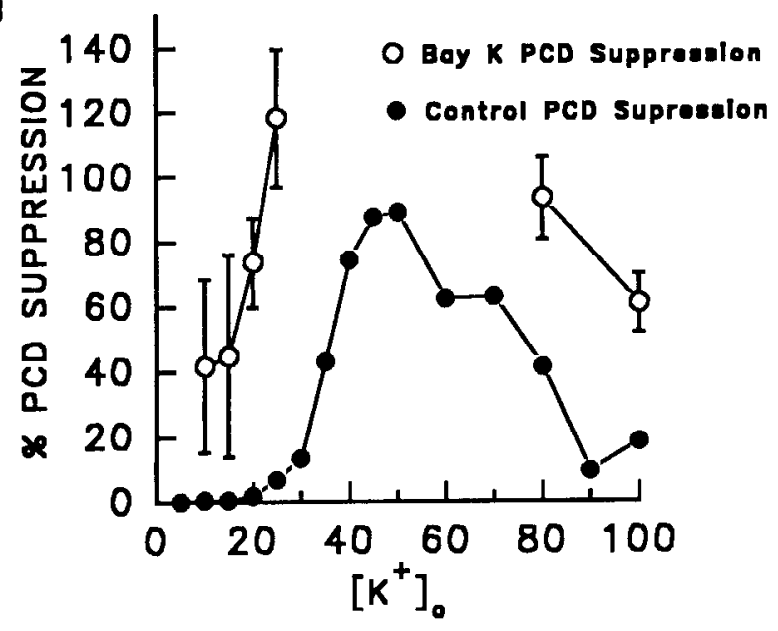

C

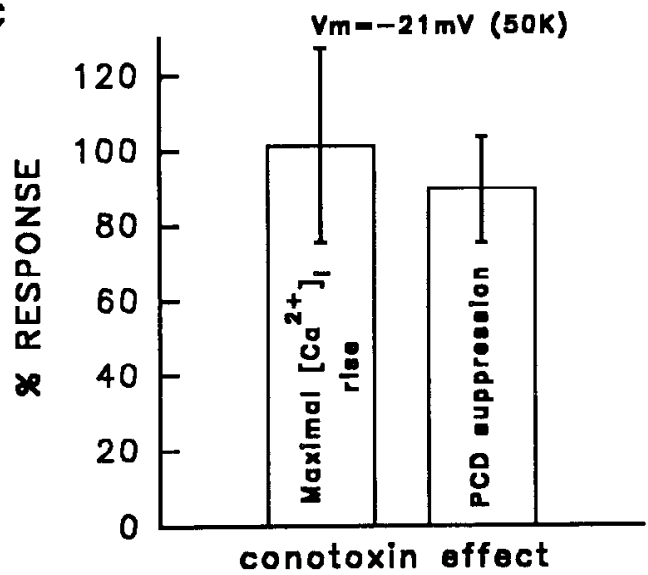

Figure 8. Effects of $\mathrm{Ca}^{2+}$ channel antagonists and agonists on survival and $\left[\mathrm{Ca}^{2+}\right]_{i} . A$, Nifedipine blocked both survival and the sustained rise of $\left[\mathrm{Ca}^{2+}\right]_{i}$ in neurons maintained in $50 \mathrm{~K}$. No additional block of survival or $\left[\mathrm{Ca}^{2+}\right]_{i}$ increase was observed with nifedipine concentrations as high as $10 \mu \mathrm{M}$. For each survival data point, $N=7-14$ from three or four platings for concentrations $\geq 1 \mathrm{nM}$; for concentrations $<1 \mathrm{nM}, N=3-$ 4 from one plating. For each $\left[\mathrm{Ca}^{2+}\right]_{i}$ data point, $N=50-100$ from two to four platings. The smooth curves are fits of the data to a logistic equation. $B$, The DHP agonist $( \pm)$ Bay K $8644(3 \mu \mathrm{M}$ and $10 \mu \mathrm{M}$ data combined) potentiated survival of NGF-deprived cells maintained in $\left[\mathrm{K}^{+}\right]_{o}$ that did not promote survival in the absence of the agonist. Solid miss rapid transient changes of $\left[\mathrm{Ca}^{2+}\right]_{i}$ caused by brief electrical activity.

\section{Pharmacology of depolarization-mediated PCD suppression and $\left[\mathrm{Ca}^{2+}\right]_{\mathrm{i}}$ increase}

Depolarization-enhanced survival is blocked by $\mathrm{Ca}^{2+}$ channel antagonists in a number of types of neurons (Nishi and Berg, 1981; Gallo et al., 1987; Koike et al., 1989) suggesting that $\mathrm{Ca}^{2+}$ influx through voltage-gated channels mediates the effect. A $\mathrm{Ca}^{2+}$ channel antagonist, the dihydropyridine (DHP) antagonist isradipine (PN200-110), blocks depolarization-enhanced survival of chicken ciliary ganglion neurons in culture (Collins and Lile, 1989) and also reduces sustained elevation of $\left[\mathrm{Ca}^{2+}\right]_{i}$ caused by depolarization of these cells (Collins et al., 1991). Similar experiments investigating the effects of DHP antagonists on sustained increases of $\left[\mathrm{Ca}^{2+}\right]_{i}$ induced by chronic depolarization have not been done with other types of neurons. About $50 \%$ of the transient rise of $\left[\mathrm{Ca}^{2+}\right]_{i}$ induced by acute depolarization of rat SCG neuronal somas with medium containing $50 \mathrm{~K}$ is sensitive to block by the DHP Ca ${ }^{2+}$ channel antagonist nitrendipine $(1 \mu \mathrm{M})$ while the more sustained portion of the $\left[\mathrm{Ca}^{2+}\right]_{i}$ increase is reduced about $77 \%$ by the same nitrendipine concentration (Thayer et al., 1987). Three other DHP antagonists, nimodipine, nifedipine, and nicardipine, have been reported to block depolarization-enhanced survival of these neurons $(1 \mu \mathrm{M}, 5 \mu \mathrm{M}$, and $5 \mu \mathrm{M}$, respectively, were tested) while DHP agonists potentiate survival (Koike et al., 1989). However, we found that similar concentrations of at least some DHP antagonists (nifedipine and nicardipine were tested) can be toxic to SCG neurons maintained in culture in the presence of NGF (data not shown). Therefore, we tested the effects of lowcr concentrations of nifedipine, which did not affect control survival, on both $\left[\mathrm{Ca}^{2+}\right]_{i}$ and survival of chronically depolarized, NGF-deprived cells (Fig. $8 A$ ). In neurons maintained in $50 \mathrm{~K}$, increasing concentrations of nifedipine caused a dose-dependent decrease of survival and of the sustained elevation of $\left[\mathrm{Ca}^{2+}\right]_{i}$ induced by the depolarization. Maximal block of the $\left[\mathrm{Ca}^{2+}\right]_{i}$ increase occurred in concentrations of nifedipine greater than or equal to $1 \mu \mathrm{M}(87$ $\pm 10 \%$ block in $1 \mu \mathrm{M}$ ). Maximal block of survival occurred in $10 \mathrm{~nm}$ nifedipine, a concentration that had no effect on the survival of control cells (data not shown). The $\mathrm{IC}_{50}$ values for block of the sustained rise of $\left[\mathrm{Ca}^{2+}\right]_{i}$ and survival by nifedipine were $\approx 4 \mathrm{nM}$ and $\approx 0.5 \mathrm{nM}$, respectively. These $\mathrm{IC}_{50}$ values are in the range of nifedipine concentrations that are highly selective for block of DHP-sensitive, or L-type, $\mathrm{Ca}^{2+}$ channels (Fox et al., 1987; Porzig, 1990; Triggle, 1990). These data suggest that

circles represent mean PCD suppression in neurons maintained in the same $\left[\mathrm{K}^{+}\right]_{o}$ without $( \pm$ )Bay K 8644 (from Fig. $6 \mathrm{C}$ ). $N=3-7$ from one or two platings for each data point. $\left[\mathrm{K}^{+}\right]_{0}$ is shown rather than $V_{m}$ because $V_{m}$ of neurons exposed to $( \pm)$ Bay $\mathrm{K} 8644$ was not measured and the agonist may depolarize neurons by increasing $\mathrm{Ca}^{2+}$ channel activity. $C$. Conotoxin did not affect either suppression of PCD by chronic depolarization with $50 \mathrm{~K}$ (10 $\mu \mathrm{M}$ fraction MVIIA; $1 \mu \mathrm{M}$ GVIA was also tested, data not shown) or sustained elevation of $\left[\mathrm{Ca}^{2+}\right]_{i}$ (fraction GVIA, $1 \mu \mathrm{M}$ ); $N=4$ and 25, respectively, from one plating for each treatment. All survival was determined in cells depolarized for $4 \mathrm{~d}$ after NGF withdrawal and is shown as percentage PCD suppression caused by depolarization with $50 \mathrm{~K}$. Percent maximal response for $\left[\mathrm{Ca}^{2+}\right]_{i}$ is percentage of increase of $\left[\mathrm{Ca}^{2+}\right]_{i}$ caused by $50 \mathrm{~K}$ without the drugs. $\left[\mathrm{Ca}^{2+}\right]_{i}$ was measured $6 \mathrm{~d}$ after plating in neurons that had been depolarized for 24-28 hr. Drugs were added $2-5 \mathrm{hr}$ before measurements were made. 

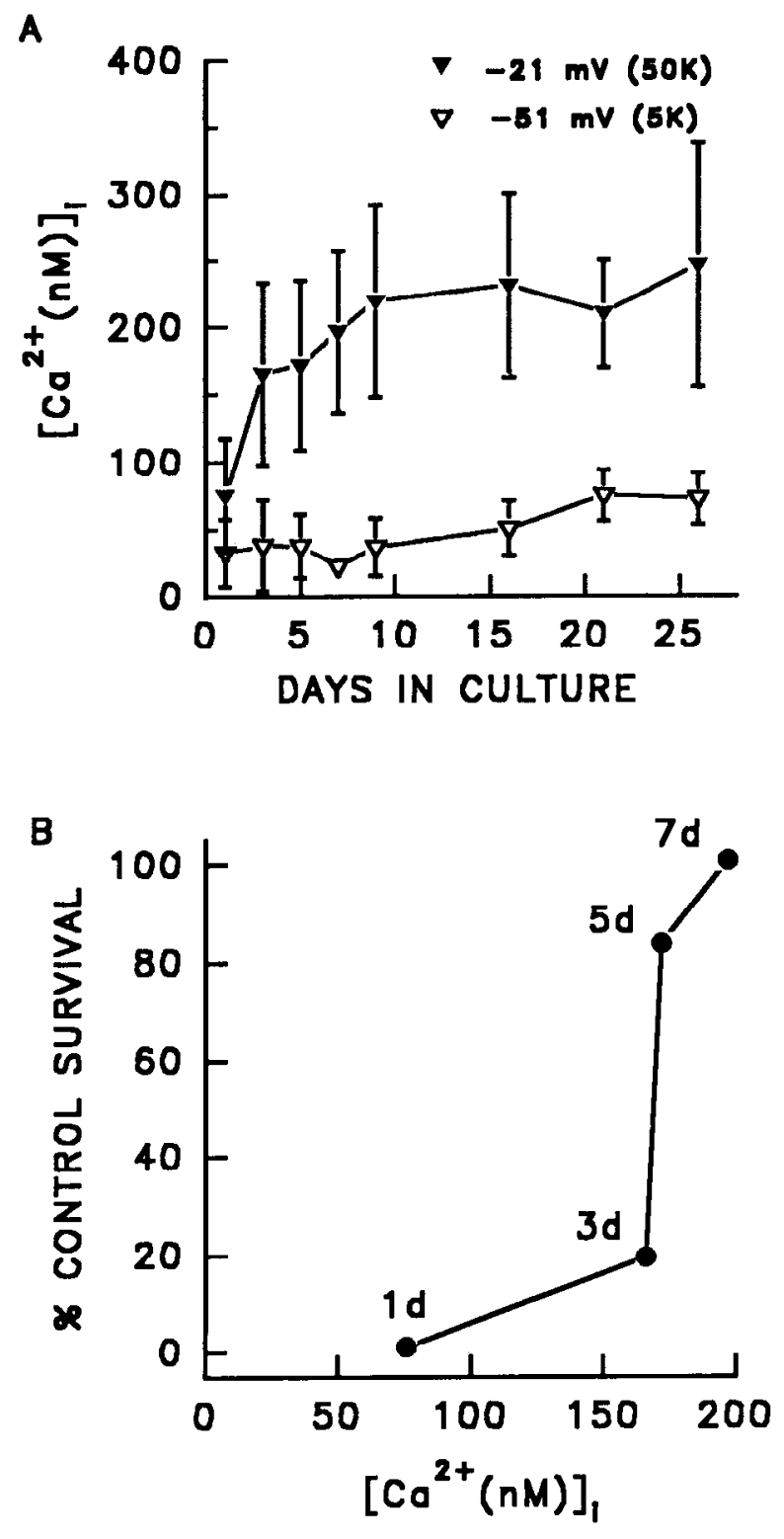

Figure 9. Development of the ability of chronic depolarization to cause a sustained increase of $\left[\mathrm{Ca}^{2+}\right]_{i} . A$, Effects of depolarization with $50 \mathrm{~K}$ on $\left[\mathrm{Ca}^{2+}\right]_{i}$ of neurons maintained in the presence of NGF for $1-26 \mathrm{~d}$ after plating. While the ability of depolarization to cause a prolonged rise of steady state $\left[\mathrm{Ca}^{2+}\right]_{i}$ increased substantially over this period, only a small increase in control $\left[\mathrm{Ca}^{2+}\right]_{i}$ was seen. For measurement of $\left[\mathrm{Ca}^{2+}\right]_{i}$, control neurons (5K) were maintained in a medium consisting of $140 \mathrm{mM} \mathrm{NaCl}$, $3 \mathrm{~mm} \mathrm{KCl}, 5 \mathrm{~mm}$ HEPES-Na-HEPES (pH 7.4), $2.4 \mathrm{~mm} \mathrm{CaCl}_{2}, 0.72$ $\mathrm{gm} / 100 \mathrm{ml}$ glucose, and $0.8 \mathrm{~mm} \mathrm{MgCl}_{2}$. Neurons were depolarized to $-21 \mathrm{mV}$ for $2-4 \mathrm{hr}$ with culture medium containing $50 \mathrm{mM} \mathrm{KCl}$ and $90 \mathrm{~mm} \mathrm{NaCl}$. They were then placed in the above medium containing $50 \mathrm{mM} \mathrm{KCl}$ and $90 \mathrm{~mm} \mathrm{NaCl}$ for measurement of $\left[\mathrm{Ca}^{2+}\right]_{i}$. In one experiment neurons maintained in the standard culture medium with $50 \mathrm{~K}$ during measurement (see Materials and Methods) gave similar results. $N=52-155$ from one to three platings for each data point. $B$, Comparison of the ability of depolarization to promote survival of NGFdeprived neurons at different times after plating with its ability to cause a sustained elevation of $\left[\mathrm{Ca}^{2+}\right]_{i}$. Survival data were taken from Figure $2 B$ and $\left[\mathrm{Ca}^{2+}\right]_{i}$ from Figure $9 A$.

block of PCD by depolarization was caused by increased $\left[\mathrm{Ca}^{2+}\right]_{i}$ caused primarily by influx of $\mathrm{Ca}^{2+}$ through L-type channels.

Koike et al. (1989) reported that DHP Ca ${ }^{2+}$ channel agonists potentiate the effect of elevated $\left[\mathrm{K}^{+}\right]_{0}$ on survival of NGF-de- prived rat SCG neurons. We confirmed this with the DHP Ca ${ }^{2+}$ channel agonist $( \pm$ )Bay K 8644, which increases L channel opentime and, subsequently, $\mathrm{Ca}^{2+}$ influx. This agonist increased survival of NGF-deprived neurons maintained in $\left[\mathrm{K}^{+}\right]_{0}$ that had little or no effect on survival in its absence (Fig. $8 B$ ). Intracellular $\mathrm{Ca}^{2+}$ was also substantially increased above control levels by $( \pm)$ Bay $\mathrm{K} 8644$. In neurons maintained in $20 \mathrm{~K}$ for $24-27 \mathrm{hr}$ without the agonist, $\left[\mathrm{Ca}^{2+}\right]_{i}$ was $64 \pm 19 \%(N=75)$ of the sustained rise in cells maintained in $50 \mathrm{~K}$ for $24-27 \mathrm{hr}$, with $( \pm)$ Bay K $8644,\left[\mathrm{Ca}^{2+}\right]_{i}$ was $98 \pm 38 \%(N=25)$ of the rise. These data provide further evidence that influx of $\mathrm{Ca}^{2+}$ through L-type channels was the relevant factor determining survival. Additional evidence was provided by the effects of the L-type $\mathrm{Ca}^{2+}$ channel antagonist, verapamil (Triggle, 1990). Verapamil caused a dose-dependent suppression of survival in NGF-dcprived cells held at $-21 \mathrm{mV}$ with $50 \mathrm{~K}$. The $\mathrm{IC}_{50}$ of this block was about $2.5 \mu \mathrm{M}(N=7-10$ for each concentration; data not shown). Verapamil blocked the sustained elevation of $\left[\mathrm{Ca}^{2+}\right]_{i}$ induced by $50 \mathrm{~K}$ with an $\mathrm{IC}_{50}$ of about $1.7 \mu \mathrm{M}(N=25$ for each concentration; data not shown).

$\omega$-Conotoxins GVIA (McClesky et al., 1987; Sher and Clementi, 1991) and MVIIA (Gray et al., 1988; Olivera et al., 1990) are antagonists of the non-DHP-sensitive, N-type (Fox et al., 1987; Plummer et al., 1989) $\mathrm{Ca}^{2+}$ channels of many types of neurons (Regan et al., 1991). $\omega$-Contoxin does not affect L-type channels in rat SCG neurons. Since nifedipine maximally blocked $87 \pm 10 \%$ of the sustained rise of $\left[\mathrm{Ca}^{2+}\right]_{i}$ caused by depolarization in these cells, it appears that, little, or none, of the increase of $\left[\mathrm{Ca}^{2+}\right]_{i}$ was caused by influx of $\mathrm{Ca}^{2+}$ through $\mathrm{N}$-type channels. Application of $\omega$-conotoxins to cultures deprived of NGF and depolarized with $50 \mathrm{~K}$ had no effect on survival $(1 \mu \mathrm{M}$ GVIA and $10 \mu \mathrm{M}$ MVIIA tested) or [ $\left.\mathrm{Ca}^{2+}\right]_{i}(1 \mu \mathrm{M}$ GVIA tested) confirming that $\mathrm{N}$-type channels made no contribution to either depolarization-increased survival or elevation of $\left[\mathrm{Ca}^{2+}\right]_{i}$ (Fig. $8 C$ ). Therefore, prevention of PCD by depolarization in rat SCG neurons appears to be entirely, or almost entirely, mediated by $\mathrm{Ca}^{2+}$ influx through DHP-sensitive channels.

\section{Development of chronic depolarization-induced increase of steady-state $\left[\mathrm{Ca}^{2+}\right]_{\mathrm{i}}$}

To determine whether the inability of elevated $\left[\mathrm{K}^{+}\right]_{0}$ to block PCD during the first few days after plating (Figs. 1,2) may reflect an inability to increase $\left[\mathrm{Ca}^{2+}\right]_{i}$ during this period, neurons were depolarized with $50 \mathrm{~K}$ at various times after plating and the effect on $\left[\mathrm{Ca}^{2+}\right]_{i}$ measured (Fig. 9A). One day after plating, steadystate $\left[\mathrm{Ca}^{2+}\right]_{i}$ in cells depolarized with $50 \mathrm{~K}$ for $2-4 \mathrm{hr}$ was considerably smaller ( $76 \pm 42 \mathrm{nM}, N=150$ ) than that of cells depolarized for the same period with $50 \mathrm{~K}$ several days after plating. By the third day after plating, depolarization with $50 \mathrm{~K}$ for 2-4 $\mathrm{hr}$ induced a sustained increase of mean steady-state $\left[\mathrm{Ca}^{2+}\right]_{i}$ equal in magnitude to that produced after $5 \mathrm{~d}$ in culture by this concentration ( $166 \pm 68 \mathrm{nM}$ and $172 \pm 63 \mathrm{nM}$, respectively; $p>0.05$ ). The ability of depolarization to cause a sustaincd rise of $\left[\mathrm{Ca}^{2+}\right]_{i}$ reached a maximum by $9 \mathrm{~d}$ after plating. In cells of this or greater age, the sustained rise of $\left[\mathrm{Ca}^{2+}\right]_{i}$ caused by a $2-4 \mathrm{hr}$ depolarization with $50 \mathrm{~K}$ was not significantly different than that of cells depolarized with $50 \mathrm{~K} 16,21$, and $26 \mathrm{~d}$ after plating ( $220 \pm 72$ for $9 \mathrm{~d}$ cells, e.g., compared to $211 \pm$ $40 \mathrm{~nm}$ for $21 \mathrm{~d}$ cells; $p>0.05 ; N=114$ and 52 , respectively).

Figure $9 B$ shows the development of depolarization-enhanced survival as a function of increased steady-state $\left[\mathrm{Ca}^{2}\right]_{i}$ elicited by the same $\left[\mathrm{K}^{+}\right]_{o}$ at the same time. Mean $\left[\mathrm{Ca}^{2+}\right]_{i}$ in neurons 
depolarized with $50 \mathrm{~K} 1 \mathrm{~d}$ after plating was well below the mean $\left[\mathrm{Ca}^{2+}\right]_{i}$ of neurons depolarized with $50 \mathrm{~K}$ for the same period 5$7 \mathrm{~d}$ after plating. However, by the third day after plating, the mean $\left[\mathrm{Ca}^{2+}\right]_{i}$ in cells treated with $50 \mathrm{~K}$ was well within this range, yet most of these neurons did not survive NGF deprivation. These data suggest that while an increase in the ability of depolarization to increase $\left[\mathrm{Ca}^{2+}\right]_{i}$ may be necessary for development of the ability of depolarization to promote survival, alone, it may not be sufficient.

Koike and Tanaka (1991) reported that $\left[\mathrm{Ca}^{2+}\right]_{i}$ in rat SCG neurons maintained in control medium $(5 \mathrm{~K})$ containing NGF for the first 3-4 weeks after plating increases to approximately the concentrations caused by chronic depolarization with optimal survival-promoting $\left[\mathrm{K}^{+}\right]_{0}$. They suggested this increase may explain why NGF deprivation takes longer to kill older neurons in vitro and in vivo. In our hands, however, only a small increase of $\left[\mathrm{Ca}^{2+}\right]_{i}$ was seen in cells maintained in NGF for this period (Fig. $9 A$ ). On the first day after plating, mean $\left[\mathrm{Ca}^{2+}\right]_{i}$ was $32 \pm .25 \mathrm{~nm}$; by $26 \mathrm{~d}$ after plating, mean $\left[\mathrm{Ca}^{2+}\right]_{i}$ had increased to $73 \pm 19 \mathrm{nM}(p<0.05)$, a rise smaller than that associated with PCD prevention by depolarization. These data suggest it is unlikely that development of decreased requirement for trophic factor (for survival) with time can be explained on the basis of increased $\left[\mathrm{Ca}^{2+}\right]_{i}$ as the cells age.

\section{Relationship between survival and $\left[\mathrm{Ca}^{2+}\right]_{\mathrm{i}}$}

The relationship between $V_{m}$ and mean $\left[\mathrm{Ca}^{2+}\right]_{i}$ was roughly similar to that between $V_{m}$ and mean survival. Both mean $\left[\mathrm{Ca}^{2+}\right]_{i}$ in cells depolarized for 24-27 $\mathrm{hr}$ (Fig. $7 B$ ) and mean survival after $4 \mathrm{~d}$ (Fig. 6A) and $10 \mathrm{~d}$ (Fig. $6 \mathrm{~B}$ ) of depolarization after NGF deprivation increased with increasingly lower $V_{m}$ values to a maximum at about -21 to $-23 \mathrm{mV}$ and then declined at lower $V_{m}$ values. Decreasing $\left[\mathrm{Ca}^{2+}\right]_{i}$ in depolarized, NGF-deprived neurons with selective concentrations of $\mathrm{Ca}^{2+}$ channel antagonists blocked both survival and the sustained rise of $\left[\mathrm{Ca}^{2+}\right]_{i \text {. }}$ Koike et al. (1989) reported that reducing $\mathrm{Ca}^{2+}$ concentration in the culture medium also blocks the survival-promoting effects of elevated $\left[\mathrm{K}^{+}\right]_{o}$ on SCG neurons. We confirmed this result. Calcium in the culture medium was reduced by adding $1 \mathrm{~mm}$ EGTA to medium in which the only added $\mathrm{Ca}^{2+}$ was that contained in the $10 \%$ fetal bovine serum. Neurons maintained in this medium in the presence of NGF lived while those maintained in 50K without NGF did not (data not shown). Taken together these data clearly indicate that a DHP-sensitive influx of $\mathrm{Ca}^{2+}$ is required for depolarization to prevent $\mathrm{PCD}$ of these neurons and suggest that the sustained rise of $\left[\mathrm{Ca}^{2+}\right]_{i}$ in depolarized cells may mediate the effect of depolarization on survival. However, as illustrated in Figure 10, the relationship between survival and $\left[\mathrm{Ca}^{2+}\right]_{i}$ in depolarized neurons was not clear-cut. Figure $10 \mathrm{~A}$ shows which mean $\left[\mathrm{Ca}^{2+}\right]_{i}$ of neurons held at $V_{m}$ values between -51 and $-5 \mathrm{mV}$ for $24-27 \mathrm{hr}$ are significantly different (by ANOVA). Figure $10 B$ shows the relationship between survival of cells maintained for $4 \mathrm{~d}$ without NGF at $V_{m}$ values between -51 and $-21 \mathrm{mV}$ and $\left[\mathrm{Ca}^{2}\right]_{i}$ in cells maintained for $24-27 \mathrm{hr}$ at the same $V_{m}$ values. It is apparent that survival varies widely at $\left[\mathrm{Ca}^{2+}\right]_{t}$ values that are not significantly different from one another. For example, $-21,-28$, and $-31 \mathrm{mV}$ cause similar sustained rises of $\left[\mathrm{Ca}^{2+}\right]_{i}(p>0.05$; from Fig. 10A) while percentage suppression of PCD at these $V_{m}$ values was $89 \pm 20,45 \pm 18$, and $16 \pm 9$, respectively (all significantly different). Therefore, there was no obvious concentration-response relationship between PCD suppression and
$\left[\mathrm{Ca}^{2+}\right]_{t}$ at these $V_{m}$ values. Figure $10 \mathrm{C}$ illustrates that at $V_{m}$ values between -21 and $-5 \mathrm{mV}$ the relationship between survival and $\left[\mathrm{Ca}^{2+}\right]_{i}$ more closely resembled a graded concentration-response relationship than it did at more negative $V_{m}$ values, survival increasing to a maximum over about a $100 \mathrm{~nm}$ range of mean $\left[\mathrm{Ca}^{2+}\right]_{i}$. Even here, however, different levels of survival are associated with $\left[\mathrm{Ca}^{2+}\right]_{i}$ values that are not significantly different (for example at 10 and $-14 \mathrm{mV}$ ). Some $\left[\mathrm{Ca}^{2+}\right]_{i}$ values at $V_{m}$ values negative to $-21 \mathrm{mV}$ (Fig. 10B) that are associated with no enhanced survival are also not significantly different from $\left[\mathrm{Ca}^{2+}\right]_{i}$ associated with suppression of PCD at some $V_{m}$ values positive to $-21 \mathrm{mV}(-37,-14$, and $-10 \mathrm{mV}$, for example). At least part of the greater spread of data at more positive $V_{m}$ values may result from greater plating to plating variability for both survival and $\left[\mathrm{Ca}^{2+}\right]_{i}$ at those $V_{m}$ values than at more negative ones (see insets in Figs. $6 A$ and $7 B$ ). These findings indicate that, while DHP-sensitive $\mathrm{Ca}^{2+}$ influx is required for depolarization-enhanced survival, the relationship between survival and $\left[\mathrm{Ca}^{2+}\right]_{i}$ is more complex than previously suspected (Collins et al., 1991; Koike and Tanaka, 1991; Franklin and Johnson, 1992).

\section{Effects of calmodulin antagonists on survival and steady-state $\left[\mathrm{Ca}^{2+}\right]_{\mathrm{i}}$}

Gallo et al. (1987) report that survival of chronically depolarized rat cerebellar granule neurons in culture is blocked by calmodulin antagonists. A possible role for calmodulin in depolarization-enhanced survival of other types of neurons in culture has not been investigated. Application of the calmodulin antagonists calmidazolium and W7 to SCG neurons deprived of NGF and depolarized with $50 \mathrm{~K}$ caused a dose-dependent block of survival at concentrations that had no effect on survival of control cells (Fig. 11.A,B). The $\mathrm{IC}_{50}$ for block of survival was $\approx 400 \mathrm{nM}$ for calmidazolium and $\approx 15-20 \mu \mathrm{M}$ for W7. At concentrations of antagonists only slightly higher than those causing suppression of depolarization-enhanced survival both calmidazolium and W7 were toxic to control neurons maintained in NGF. Calmidazolium killed all neurons saved by depolarization at concentrations $\geq 750 \mathrm{~nm}$ and all control cell at $\geq 3 \mu \mathrm{M}$, including those neurons that were resistant to NGF deprivation. W7 killed all neurons saved by depolarization at concentrations $\geq 30 \mu \mathrm{M}$ and all control neurons at concentrations $\geq 70 \mu \mathrm{M}$. Control neurons killed by the antagonists did not exhibit the atrophy characteristic of PCD and cells killed by calmidazolium were not "saved" by inhibition of protein synthesis by cycloheximide as were neurons deprived of NGF (data not shown) indicating that the death caused by the antagonists was not, by these criteria, similar to PCD.

These data appear to suggest a role for calmodulin in mediating the effect of elevated $\left[\mathrm{Ca}^{2+}\right]_{i}$ on survival of NGF-deprived neurons. However, a caveat to this interpretation of the results is that inhibitors of calmodulin can block voltage-gated $\mathrm{Ca}^{2+}$ channels and reduce $\mathrm{Ca}^{2+}$ influx (Greenberg et al., 1987; Doroshenko et al., 1988). Because of this effect, block of depolarization-mediated effects by calmodulin antagonists should be interpreted with great caution. To determine whether calmodulin antagonists affected the sustained rise of $\left[\mathrm{Ca}^{2+}\right]_{i}$ caused by depolarization in SCG neurons, cells treated with $50 \mathrm{~K}$ were exposed to the antagonists. Calmidazolium caused a dose-dependent decrease of the sustained elevation of $\left[\mathrm{Ca}^{2+}\right]_{i}($ Fig. 11C) with an $\mathrm{IC}_{50}$ of $\approx 200 \mathrm{nM}$. Neurons depolarized with $50 \mathrm{~K}$ for 26-27 hr and treated for 2-3 hr with $30 \mu \mathrm{M} \mathrm{W} 7$, a concentration 
A
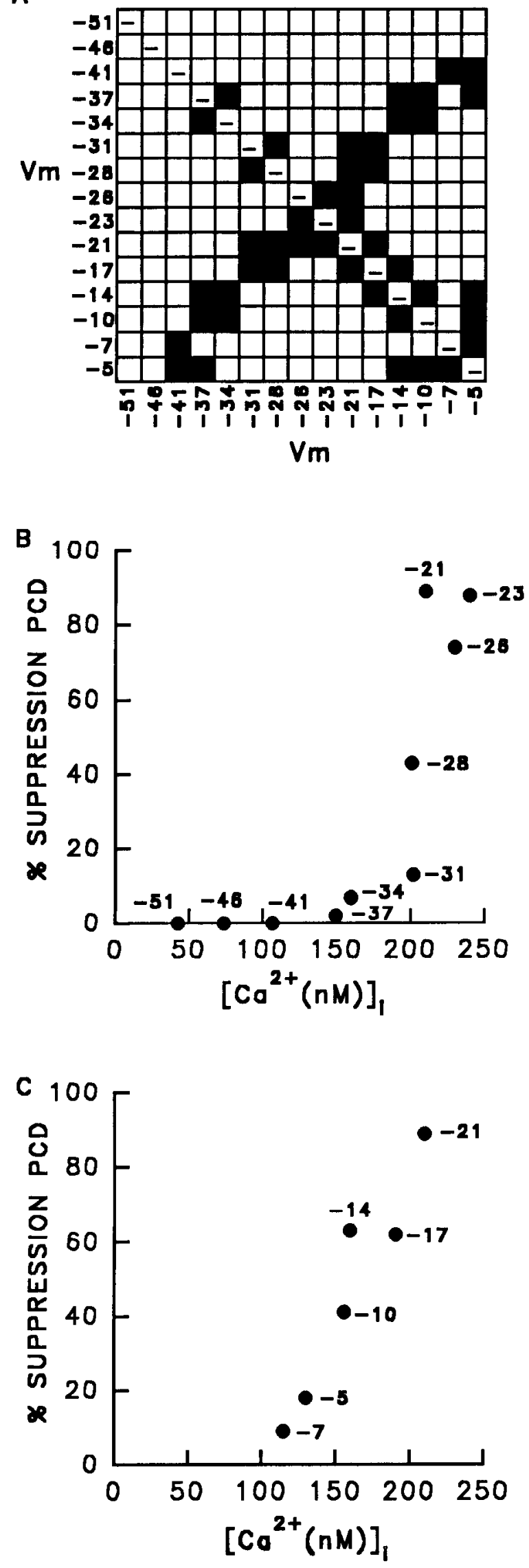

that completely blocked depolarization-enhanced survival without affecting control survival, also had $\left[\mathrm{Ca}^{2+}\right]_{i}$ reduced to $17 \pm$ $38 \%$ of the sustained rise caused by $50 \mathrm{~K}$ alone $(N=50)$. These data suggest that these antagonists blocked $\mathrm{Ca}^{2+}$ influx into these cells and also suggest that this blockade was responsible for their effect on survival. Therefore, these calmodulin antagonists cannot be used to investigate a possible role for calmodulin in depolarization-enhanced survival.

Because of the apparent effect of the calmodulin antagonists on $\mathrm{Ca}^{2+}$ influx, an alternative means of chronically increasing $\left[\mathrm{Ca}^{2+}\right]_{i}$ that is not affected by the antagonists is desirable. We have recently developed a technique that allows $\left[\mathrm{Ca}^{2+}\right]_{i}$ to be increased in these neurons without exposure to elevated $\left[\mathrm{K}^{+}\right]_{\text {o }}$. This method uses the potent and selective inhibitor of intracellular $\mathrm{Ca}^{2+}$ sequestration, thapsigargin. Treatment of cells with thapsigargin rapidly depletes intracellular $\mathrm{Ca}^{2+}$ stores. These stores are then thought to produce a second messenger that traverses the cytoplasm and activates a $\mathrm{Ca}^{2+}$ conductance in the plasma membrane (Hoth and Penner, 1992; Lückhoff and Clapham, 1992; Putney and Bird, 1993). Influx of $\mathrm{Ca}^{2+}$ through this conductance can cause a sustained increases of $\left[\mathrm{Ca}^{2+}\right]_{i}$. We have found that thapsigargin induces a DHP-insensitive sustained rise of $\left[\mathrm{Ca}^{2+}\right]_{i}$ in SCG neurons and, in combination with elevated $\left[\mathrm{Ca}^{2+}\right]_{o}$ (to increase $\mathrm{Ca}^{2+}$ driving force), prevents PCD of NGFdeprived cells (Lampe et al., 1992; Lampe et al., unpublished observations). Figure $12 A$ shows the sustained increase of $\left[\mathrm{Ca}^{2+}\right.$, induced by thapsigargin and elevated $\left[\mathrm{Ca}^{2+}\right]_{o}$. Calmidazolium had no effect on resting $\left[\mathrm{Ca}^{2+}\right]_{i}$ in control cells and did not block the sustained increase of $\left[\mathrm{Ca}^{2+}\right]_{i}$ caused by the thapsigargin and high $\left[\mathrm{Ca}^{2+}\right]_{o}$ treatment at calmidazolium concentrations that almost completely blocked the sustained increase of $\left[\mathrm{Ca}^{2+}\right]_{i}$ in depolarized neurons. These data suggest that calmidazolium does not interfere with $\mathrm{Ca}^{2+}$ influx resulting from thapsigargin/ high $\left[\mathrm{Ca}^{2+}\right]_{o}$ treatment. This lack of effect on the thapsigargininduced $\left[\mathrm{Ca}^{2+}\right]_{i}$ increase allowed NGF-deprived cells "saved" by thapsigargin and elevated $\left[\mathrm{Ca}^{2+}\right]_{\text {o }}$ to be treated with calmodulin antagonists without affecting $\mathrm{Ca}^{2+}$ influx. Figure $12 B$ shows that calmidazolium (e.g., $1 \mu \mathrm{M}$ ) did not block survival of NGFdeprived neurons supported by thapsigargin and high- $\left[\mathrm{Ca}^{2+}\right]_{o}$ treatment at the same concentrations that completely blocked survival of depolarization-"saved" cells (Fig. 11A). Survival was affected by calmidazolium in the thapsigargin/high- $\left[\mathrm{Ca}^{2+}\right]_{\mathrm{s}}$ supported neurons only at concentrations that proved toxic (2-3 $\mu \mathrm{M})$ to control cells. We did not determine whether this toxic effect was caused by block of calmodulin activity or by a nonspecific effect.

\section{Effect of depolarization on tyrosine phosphorylation}

The biologically active receptor for NGF is TrkA, a member of the tyrosine kinase family of growth factor receptors (TrkA, TrkB, TrkC; referred to here collectively as Trk) and the protein

\footnotetext{
Figure 10. Suppression of PCD by depolarization is not clearly related to mean $\left[\mathrm{Ca}^{2+}\right]_{i} . A$, Significance table comparing mean $\left[\mathrm{Ca}^{2+}\right]_{i}$ of cells depolarized to different $V_{m}$ values for $24-27 \mathrm{hr}$ (from Fig. $7 B$ ). Solid squares indicate that mean $\left[\mathrm{Ca}^{2+}\right]_{i}$ at the compared $V_{m}$ values is not significantly different (by ANOVA). $B$, Relationship between $\left[\mathrm{Ca}^{2+}\right]_{i}$ in cells depolarized for 24-27 hr and percentage suppression of PCD after $4 \mathrm{~d}$ of depolarization to $V_{m}$ values between -51 and $-21 \mathrm{mV}$. $C$, Relationship between $\left[\mathrm{Ca}^{2+}\right]_{i}$ in cells depolarized for $24-27 \mathrm{hr}$ and percentage suppression of PCD after $4 \mathrm{~d}$ of depolarization to $V_{m}$ values between -21 and $-5 \mathrm{mV}$. Survival data are taken from Figure $6 C$.
} 

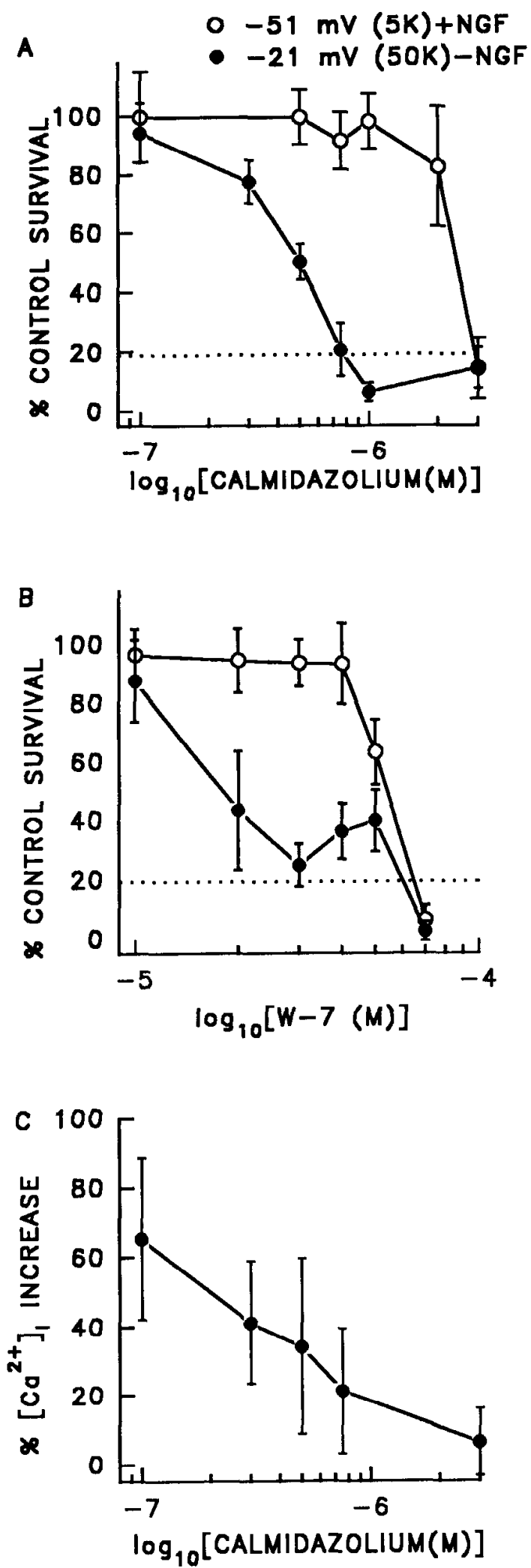

Figure 11. Effects of calmodulin antagonists on survival and $\left[\mathrm{Ca}^{2+}\right]_{i}$. Survival of neurons deprived of NGF and depolarized with $50 \mathrm{~K}$ for 4 $\mathrm{d}$ was blocked by calmidazolium $(A)$ and $\mathrm{W} 7(B)$ at concentrations that did not affect survival of control cells. Control survival is average number of neurons in sibling cultures (usually four) maintained in NGF and $5 \mathrm{~K}$ without drugs for the same period. $N=5-10$ from two platings for each data point in $A$ and $B$. Dotted lines show survival of cells in sibling $5 \mathrm{~K}$ cultures deprived of NGF without the drugs. $C$, Calmidazolium product of the trk proto-oncogene (Kaplan et al., 1991). When bound to their ligands, tyrosine kinase receptors autophosphorylate on tyrosine residues. This phosphorylation leads to a cascade of events that mediates most, if not all, of the effects of the growth factors (Schlessinger and Ullrich, 1992). The effect of increased $\left[\mathrm{Ca}^{2+}\right]_{i}$ on receptor tyrosine kinase activity has, to our knowledge, not been examined. One conceivable mechanism by which increased $\left[\mathrm{Ca}^{2+}\right]_{i}$ may support survival is by activation of TrkA in the absence of NGF. Figure 13, $A$ and $B$, shows the effects of NGF and chronic depolarization on Trk (TrkA, TrkB, and TrkC) tyrosine autophosphorylation. In neurons continuously exposed to NGF, Trk (presumably TrkA) was constitutively phosphorylated on tyrosine residues. One hour of NGF deprivation led to a $44 \%$ decrease of this phosphorylation. After 2--6 hr of deprivation, Trk phosphorylation was less than $3 \%$ of that in cells continuously exposed to NGF. When neurons were deprived of NGF for $2 \mathrm{hr}$ and then exposed to NGF, Trk became rapidly phosphorylated on tyrosine residues. Five minutes after NGF addition, Trk phosphorylation had increased to $226 \%$ of the level found in cells continuously exposed to NGF. When NGF-deprived cells were exposed to NGF and depolarized to $-21 \mathrm{mV}$ with $50 \mathrm{~K}$, the increase in Trk phosphorylation was $217 \%$ of that in cells continuously exposed to NGF, similar to that of neurons exposed to NGF at control $V_{m}(-51 \mathrm{mV})$. When cells that had been deprived of NGF for 1,2 , or $6 \mathrm{hr}$ were exposed to $50 \mathrm{~K}$ medium containing no NGF, Trk tyrosine phosphorylation was similar to that of cells deprived for the same period $(80,8$, or $3 \%$ of control, respectively). Similar results were found in the rat pheochromocytoma cell line, PC12, when these cells were exposed to $50 \mathrm{~K}$ (data not shown). Therefore, depolarization had little effect on Trk autophosphorylation and activation of Trk tyrosine kinase activity is probably not the mechanism by which depolarization promotes survival.

While Trk tyrosine phosphorylation was not substantially affected by depolarization, analysis of total cell lysates showed a single protein band with a molecular weight of about $44 \mathrm{kDa}$ that had increased tyrosine phosphorylation when neurons were exposed to either NGF or $50 \mathrm{~K}$ (Fig. 13C). The molecular weight of this protein suggests that it might be an extracellular signalregulated protein kinase (ERK; Boulton et al., 1991). These kinases are important signaling molecules in growth factor signal transduction. If this protein is an ERK, the NGF and $\left[\mathrm{Ca}^{2+}\right]_{i}$ signal transduction pathways for survival may converge at this point. The data shown in Figure 14 support the possibility that $\mathrm{NGF}$ and elevated $\left[\mathrm{K}^{+}\right]_{o}$ may utilize similar transduction pathways to promote survival. These data demonstrate that both NGF and 50K "rescued" NGF-deprived neurons over the same time course. Other agents that can rescue NGF-deprived cells (e.g., cycloheximide) do not follow this time course (Deckwerth and Johnson, 1993). In addition to the $44 \mathrm{kDa}$ protein, NGF caused tyrosine phosphorylation of two proteins with molecular weights of approximately 80 and $95 \mathrm{kDa}$, respectively. Since these proteins were not tyrosine phosphorylated by depolariza-

caused a dose-dependent block of the sustained rise of $\left[\mathrm{Ca}^{2+}\right]$ caused by chronic depolarization with $50 \mathrm{~K}$. Percent $\left[\mathrm{Ca}^{2+}\right]_{i}$ increase is percentage of increase caused by $50 \mathrm{~K}$ without the drug. Cells were depolarized for 23-28 hr and exposed to calmidazolium for 2-5 hr before $\left[\mathrm{Ca}^{2+}\right]_{i}$ measurements were made. $N=74-75$ from three platings for each data point. 

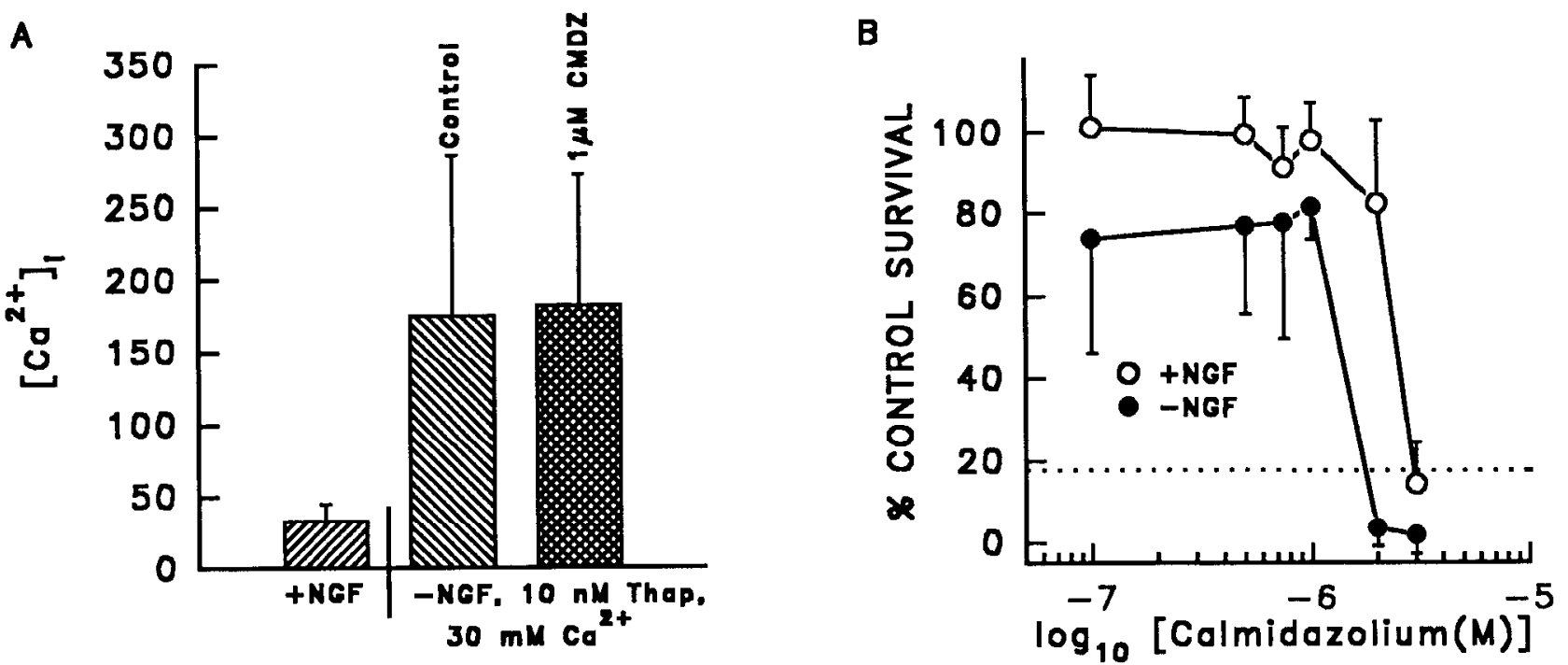

Figure 12. Effect of calmidazolium on survival and the sustained rise of $\left[\mathrm{Ca}^{2+}\right]_{i}$ in cells maintained in thapsigargin and $30 \mathrm{~mm} \mathrm{Ca}^{2+} . A$, Calmidazolium $(C M D Z)$ did not decrease a sustained rise of $\left[\mathrm{Ca}^{2+}\right]_{i}$ induced by thapsigargin (Thap) and elevated $\left[\mathrm{Ca}^{2+}\right]_{o}$. Deprived neurons were maintained in medium with $30 \mathrm{mM} \mathrm{Ca}^{2+}$ and $10 \mathrm{nM}$ thapsigargin for $22-27 \mathrm{hr}$ and in calmidazolium for $3-4 \mathrm{hr}$ before measurements were made. $N=50-75$ from two or three platings for each treatment. $B$, Calmidazolium killed neurons maintained in thapsigargin and elevated [Ca $\left.{ }^{2+}\right]_{0}($ solid circles) at approximately the same concentrations that killed control neurons maintained in NGF and standard culture medium. NGF was withdrawn from neurons $5 \mathrm{~d}$ after plating and cells were exposed to $10 \mathrm{nM}$ thapsigargin, $30 \mathrm{~mm}\left[\mathrm{Ca}^{2+}\right]_{o}$, and calmidazolium for $4 \mathrm{~d}$. Survival was then assayed. Control survival is average number of neurons in sibling cultures maintained in NGF and $5 \mathrm{~K}$ without drug for the same period. Dotted lines show survival of cells in sibling control cultures deprived of NGF without calmidazolium. $N=5-8$ from two platings for each data point.

tion, they are unlikely to be part of the signal transduction pathway by which depolarization promotes survival.

\section{Discussion}

The purpose of this study was to provide insight into the mechanisms by which elevated $\left[\mathrm{K}^{+}\right]_{\diamond}$ prevents neuronal $\mathrm{PCD}$. To this end we analyzed and compared the effects of elevated $\left[\mathrm{K}^{+}\right]_{0}$ on the $V_{m}$, growth, $\left[\mathrm{Ca}^{2+}\right]_{i}$, and survival of rat SCG neurons deprived of NGF in culture. Elevated $\left[\mathrm{K}^{+}\right]_{0}$ caused chronic depolarization of neurons and a sustained increase of steady-state $\left[\mathrm{Ca}^{2+}\right]_{i}$. This $\left[\mathrm{Ca}^{2+}\right]_{i}$ rise appeared to be caused primarily by DHP-sensitive $\mathrm{Ca}^{2+}$ influx. By the fifth day after plating depolarization with medium containing $50 \mathrm{mM} \mathrm{K}^{+}$prevented death of most NGF-deprived cells. Small decreases of $V_{m}$ were associated with large changes in survival. The relevant parameter suppressing PCD of NGF-deprived cells maintained in high $\left[\mathrm{K}^{+}\right]_{D}$ appeared to be $\mathrm{Ca}^{2+}$ influx rather than depolarization since the DHP Ca ${ }^{2+}$ channel antagonist, nifedipine, blocked both depolarization-enhanced survival and increased $\left[\mathrm{Ca}^{2+}\right]_{i}$ at similar low concentrations. Additionally, lowering $\left[\mathrm{Ca}^{2+}\right]_{o}$ blocked the ability of depolarization to suppress PCD. While these data strongly suggest that increased $\left[\mathrm{Ca}^{2+}\right]_{i}$ mediates depolarizationenhanced survival there was no clear correlation between measured $\left[\mathrm{Ca}^{2+}\right]_{i}$ at different $V_{m}$ values and the ability of those $V_{m}$ values to promote survival. This lack of correlation suggests that the relationship between $\left[\mathrm{Ca}^{2+}\right]_{i}$ and survival is more complex than we (Franklin and Johnson, 1992), and others (Collins et al., 1991; Koike and Tanaka, 1991), have previously supposed. Chronic depolarization with $50 \mathrm{mM} \mathrm{K}^{+}$was ineffective in preventing death of freshly plated neurons deprived of NGF. This may be, in part, because this treatment did not appear to cause a substantial $\mathrm{Ca}^{3+}$ influx in these cells. While survival in the absence of NGF was supported by chronic depolarization, growth of cells was greatly reduced when NGF was removed from the culture medium.

We also investigated possible signal transduction pathways by which depolarization-induced $\mathrm{Ca}^{2+}$ influx may be translated into enhanced survival. Calmodulin antagonists blocked the depolarization-enhanced survival of NGF-deprived cells at concentrations that did not affect control cells but apparently did so by blocking $\mathrm{Ca}^{2+}$ influx rather than through an effect on calmodulin. $\Lambda \mathrm{t}$ slightly higher concentrations, calmodulin antagonists were toxic to control cells and to NGF-deprived cells "saved" by increased $\mathrm{Ca}^{2+}$ influx induced by thapsigargin/high $\left[\mathrm{Ca}^{2+}\right]_{o}$; therefore, it was not possible to use these compounds to obtain insight into whether calmodulin was involved in the effect of increased $\left[\mathrm{Ca}^{2+}\right]_{i}$ on survival. Depolarization to optimal survival-promoting $V_{m}$ had little effect on autophosphorylation of Trk indicating that activation of the Trk tyrosine kinase was probably not the mechanism by which $\mathrm{Ca}^{2+}$ influx promoted survival. Both NGF and depolarization caused tyrosine phosphorylation of a protein with a molecular weight of about 44 $\mathrm{kDa}$.

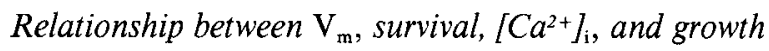

Chalazonitis and Fischbach (1980) used intracellular recording techniques to demonstrate that prolonged exposure of embryonic chicken dorsal root ganglion (DRG) neurons in cell culturc to a wide range of elevated $\left[\mathrm{K}^{+}\right]_{o}(1-100 \mathrm{~mm})$ causes these neurons to become chronically depolarized to a wide range of $V_{m}$ values. They also found that prolonged exposure to high $\left[\mathrm{K}^{+}\right]_{o}$ enhances survival of these neurons. However, only two $\mathrm{K}^{+}$concentrations were used for the survival experiments so the influence of a wide range of $V_{m}$ values on survival of these cells was not determined. To ascertain the relationship between $V_{m}$ and survival of NGF-deprived rat SCG neurons, we used the tight- 


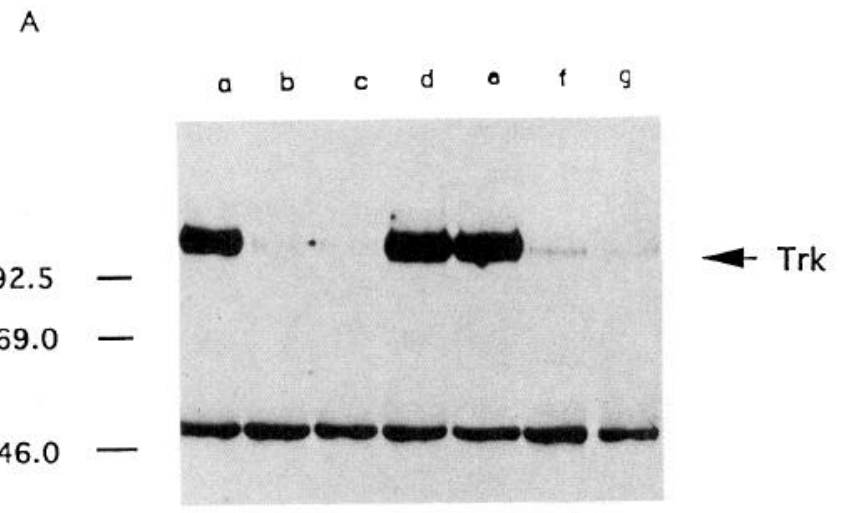

B

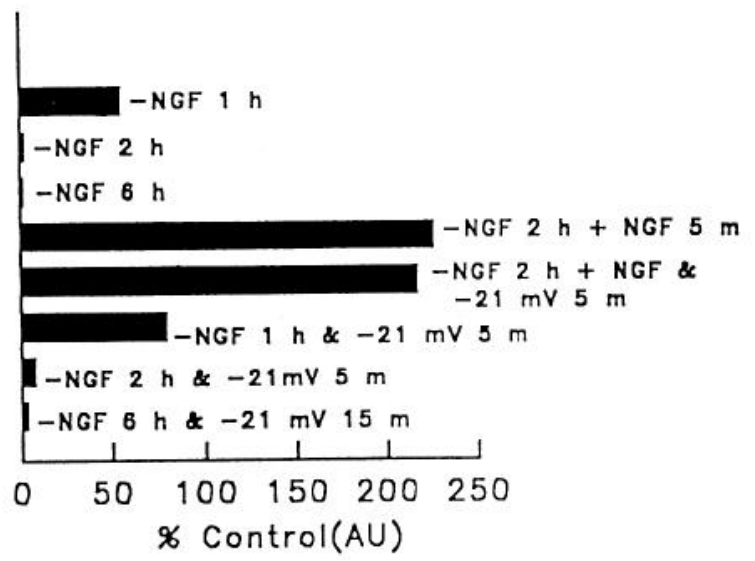

C

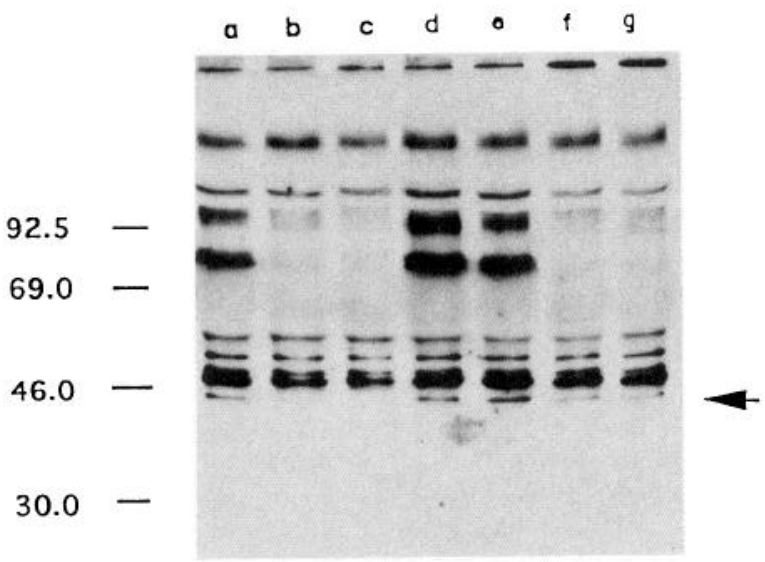

Figure 13. Effect of NGF and depolarization on tyrosine phosphorylation. $A$, Immunoblot illustrating the effects of NGF and depolarization with $50 \mathrm{~K}(-21 \mathrm{mV})$ on Trk tyrosine autophosphorylation. Lanes: $a$, Control, tyrosine phosphorylation of Trk in SCG neurons continuously exposed to NGF; $b$ and $c, 2$ or $6 \mathrm{hr}$ after NGF deprivation in $5 \mathrm{~K} ; d, 2$ $\mathrm{hr}$ of deprivation followed by $5 \mathrm{~min}$ exposure to NGF in $5 \mathrm{~K} ; e, 2 \mathrm{hr}$ of deprivation followed by $5 \mathrm{~min}$ exposure to $\mathrm{NGF}$ and $50 \mathrm{~K} ; f$ and $g$, NGF deprivation for $2 \mathrm{hr}$ followed by 5 or $15 \mathrm{~min}$ exposure to $50 \mathrm{~K}$ without NGF. Depolarization had little effect on Trk autophosphorylation either in the absence or presence of NGF. The lower bands are IgGs. B, Quantification by densitometry of Trk tyrosine autophosphorylation in cells receiving the indicated treatments. Data is normalized to phosphorylation of Trk in cells continuously exposed to NGF $(A U$, absorbance units). Data was taken from the immunoblot in $A$ except for the $1 \mathrm{hr}$ data, which was taken from a different immunoblot. $C$, Immunoblot showing tyrosine phosphorylation of proteins in lysates of the cells used for the immunoprecipitation of Trk in $A$. The lanes are arranged in the

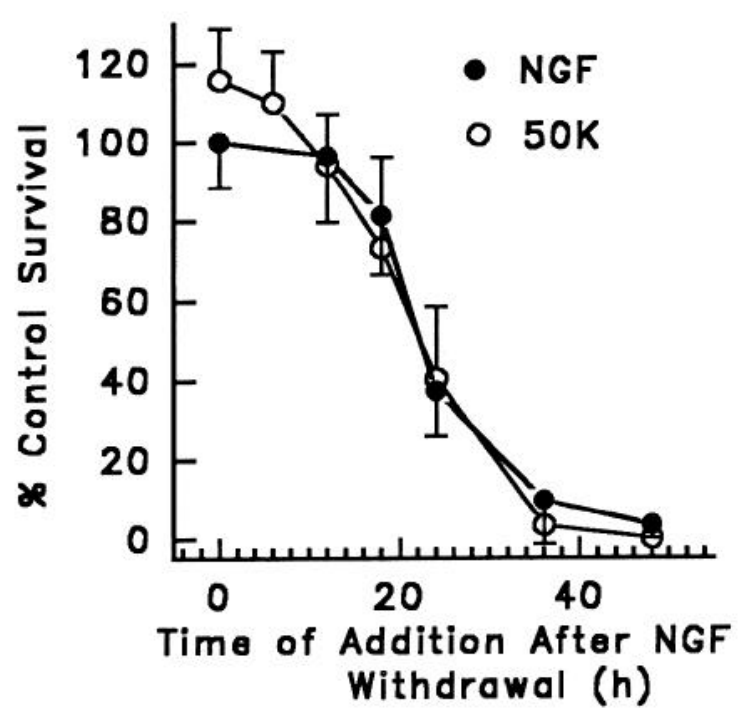

Figure 14. The time course of rescue by high $\left[\mathrm{K}^{+}\right]_{o}$ and NGF are identical. Neurons were deprived of NGF $7 \mathrm{~d}$ after plating. 50K or NGF were added at the indicated time after deprivation and survival was assayed 1 week later. Cells were dissociated by treatment with $1 \mathrm{mg}$ / $\mathrm{ml}$ dispase and $1 \mathrm{mg} / \mathrm{ml}$ collagenase. $N=8--12$ for each $50 \mathrm{~K}$ data point. NGF data is taken from Deckwerth and Johnson (1993).

seal whole-cell recording technique to measure $V_{m}$ values of neurons in all $\left[\mathrm{K}^{+}\right]_{o}$ in which the survival of NGF-deprived cells was examined. The data show that survival was steeply related to $V_{m}$, increasing from no enhanced survival to maximal enhancement over about a $13 \mathrm{mV}$ decrease of $V_{m}$. While some SCG neurons held at mean $V_{m}$ values greater than or equal to $-46 \mathrm{mV}$ fired action potentials, no neurons maintained at mean $V_{m}$ values less than $-46 \mathrm{mV}$ exhibited any electrical activity. The lack of electrical activity at potentials that saved cells from dying when deprived of NGF indicates that the critical factor for survival was the sustained depolarization rather than action potentials or synaptic potentials induced by the elevated $\left[\mathrm{K}^{+}\right]_{o}$. This was previously suggested by the work of Koike et al. (1989) showing that tetrodotoxin does not affect high $\left[\mathrm{K}^{+}\right]_{o}$ promoted survival of these cells.

Steep voltage dependence of a cellular phenomenon can indicate mediation by voltage-gated channels in the plasma membrane that have $V_{m}$ thresholds that must be exceeded for activation. This is probably not the mechanism underlying the steep relationship between survival of NGF-deprived rat SCG neurons and $V_{m}$. Intracellular $\mathrm{Ca}^{2+}$ concentration increased more gradually with increasingly lower $V_{m}$ values (between -51 and $-5 \mathrm{mV}$ ) than did survival. Thus, the steep relationship between survival and $V_{m}$ and is not explained by a $V_{m}$-dependent threshold for activation of $\mathrm{Ca}^{2+}$ channels. Scott and Fisher (1970) and Scott (1971) showed that increasing $\left[\mathrm{K}^{+}\right]_{o}$ incrementally from less than $5 \mathrm{~mm}$ to $81 \mathrm{~mm}$ gives an inverted U-shaped concentration-response curve for survival of dissociated embryonic chicken DRG neurons and human spinal ganglion neurons in culture; no explanation for this effect was given. The effect of such a wide range of $\left[\mathrm{K}^{+}\right]_{o}$ on survival of other neuronal types

same order. The arrow indicates a protein with a molecular weight of about $44 \mathrm{kDa}$ that showed increased tyrosine phosphorylation with both NGF and high $\left[\mathrm{K}^{+}\right]_{o}$ treatment. 
has not been investigated. The inverted U-shaped $V_{m}\left(\left[\mathrm{~K}^{+}\right]_{\omega}\right)$ survival curve for NGF-deprived rat SCG neurons reported here is qualitatively similar to their findings. The relationship between survival and $V_{m}$ was roughly similar to the relationship between $V_{m}$ and $\left[\mathrm{Ca}^{2+}\right]_{i}$, mean $\left[\mathrm{Ca}^{2+}\right]_{i}$ and mean survival reaching a peak in cells held at about -23 to $-21 \mathrm{mV}$ and then decreasing at more positive $V_{m}$ values. These data suggest that the inverted $\mathrm{U}$-shaped $V_{m}$-survival curve was caused by the ability of the different $V_{m}$ values to cause an adequate $\mathrm{Ca}^{2+}$ influx. The most likely explanation for decreasing $\left[\mathrm{Ca}^{2+}\right]_{i}$ at increasingly lower $V_{m}$ values is increasing steady-state inactivation of $\mathrm{Ca}^{2+}$ channels. This would result in fewer channels available to carry $\mathrm{Ca}^{2+}$ current and, subsequently, reduced $\mathrm{Ca}^{2+}$ influx.

Only after $3 \mathrm{~d}$ in culture (in NGF) did elevated $\left[\mathrm{K}^{+}\right]_{o}$ support survival of a substantial number of NGF-deprived cells. While the effect of increased $\left[\mathrm{K}^{+}\right]_{o}$ on $\left[\mathrm{Ca}^{2+}\right]_{i}$ was blunted $1 \mathrm{~d}$ after plating as compared to that of cells that had been in culture for longer periods, by the third day after plating, $\left[\mathrm{Ca}^{2+}\right]_{i}$ of cells in the same $\left[\mathrm{K}^{+}\right]_{o}$ was well within the range of concentrations of neurons "saved" by this concentration of $\left[\mathrm{K}^{+}\right]_{o}$ at later times in culture and yet few cells survived. These data suggest that factors other than the effect of depolarization on $\left[\mathrm{Ca}^{2+}\right]_{i}$ were, at least partially, responsible for development of the ability of depolarization to prevent PCD. Since NGF appears to be necessary for significant growth of neurites, one possible explanation for the development of this response is that cells must extend neurites and become well attached to the substrate in the tissue culture dish before chronic depolarization can promote their survival. Without NGF, the cells might not attach and could float off the substrate and be lost to the survival assay that was used even though they may remain alive. While this possibility might explain why cells could not be saved by depolarization at the time of plating, it cannot explain the failure of depolarization to prevent death at later times. By the third day after plating, neurons had developed neurites and appeared well attached to the culture dishes even when they were dying after NGF deprivation (data not shown). Another possibility is that neurons require NGF to recover fully from damage caused by dissociation and only after this recovery can depolarization replace NGF in supporting survival. Since depolarization promotes little growth, damage to cells caused by dissociation may not be repaired in depolarized, NGF-deprived neurons and without this repair cells cannot live. Yet another possibility is that the appropriate signal transduction pathways or mechanisms by which $\mathrm{Ca}^{2+}$ influx promotes survival are not mature in freshly plated neurons and several days of exposure to NGF are required for these pathways to become fully functional. Acheson et al. (1987) found that the ability of elevated $\left[\mathrm{K}^{+}\right]_{o}$ to support survival of embryonic chicken DRG neurons in culture is much greater with cells dissociated from day 12 than day 6 embryos. Determining whether the development of depolarization-enhanced survival of rat SCG neurons during the first week in culture is a true developmental change or an artifact of dissociation will require similar experiments examining survival of depolarized, NGF-deprived neurons dissociated from weekold rather than E21 rats. This issue will be addressed in future work.

Our results only partially confirm those of Koike and Tanaka (1991) concerning the effect of chronic depolarization on $\left[\mathrm{Ca}^{2+}\right]_{i}$ and survival of NGF-deprived embryonic rat SCG neurons in culture. We extended their results by investigating the effect of a wider range of $\left[\mathrm{K}^{+}\right]_{\omega}$ on survival and $\left[\mathrm{Ca}^{2+}\right]_{i}$, determined the $V_{m}$ values associated with the different $\left[\mathrm{K}^{+}\right]_{o}$, and determined the effects on both survival and $\left[\mathrm{Ca}^{2+}\right]_{i}$ of wide range of concentrations of a $\mathrm{Ca}^{2+}$ channel antagonist. We concur with Koike and Tanaka that $\mathrm{Ca}^{2+}$ influx is required for depolarization-enhanced survival of NGF-deprived SCG neurons. However, by doing a more complete analysis of the relationship between $\left[\mathrm{K}^{+}\right]_{o},\left[\mathrm{Ca}^{2+}\right]_{i}$, and survival, we find that Koike and Tanaka's conclusion that there is a good correlation between the sustained rise of $\left[\mathrm{Ca}^{2+}\right]_{i}$ and survival in depolarized $\mathrm{SCG}$ neurons requires reevaluation. Similarly, the conclusion of Collins et al. (1991) that their data show a good correlation between survival and a sustained rise of $\left[\mathrm{Ca}^{2+}\right]_{i}$ induced by chronic depolarization \pm DHP agonist treatment of chick embryo ciliary ganglion neurons may not be justified. In that work survival appeared to vary widely at $\left[\mathrm{Ca}^{2+}\right]_{i}$ that, by close inspection, do not appear to be significantly different. The discrepancy between our results and those of Koike and Tanaka (1991) concerning increased $\left[\mathrm{Ca}^{2+}\right]_{i}$ in control neurons as they age in culture is puzzling. However, due to a small sample number, it is not clear that the increase of $\left[\mathrm{Ca}^{2+}\right]_{i}$ they measured in older cells is significant. The small increase of mean $\left[\mathrm{Ca}^{2+}\right]_{i}$ that we measured in control cells maintained for about 4 weeks in culture was probably not enough to account for decreased trophic factor dependence. Therefore, our results are not consistent with Koike and Tanaka's suggestion that increased $\left[\mathrm{Ca}^{2+}\right]_{i}$ with age causes decreased trophic-factor dependence.

It is clear from our data and that of others (Collins et al., 1991; Koike and Tanaka, 1991; see Franklin and Johnson, 1992, for review) that $\mathrm{Ca}^{2+}$ influx is required for depolarization to promote survival. It is, therefore, surprising that there is no obvious correlation between $\left[\mathrm{Ca}^{2+}\right]_{i}$ and survival in chronically depolarized cells. There are at least two possible explanations for lack of an obvious relationship between survival and steadystate $\left[\mathrm{Ca}^{2+}\right]_{i}$. First, perhaps the sustained elevation of $\left[\mathrm{Ca}^{2+}\right]_{i}$ measured here is only loosely related to the relevant pool of $\mathrm{Ca}^{2+}$ that enhances survival. For example, the $\mathrm{Ca}^{2+}$ pool promoting survival may be highly localized near the point of $\mathrm{Ca}^{2+}$ entry into the cells. It is known that $\left[\mathrm{Ca}^{2+}\right]_{i}$ can reach very high concentrations near the cytoplasmic side of $\mathrm{Ca}^{2+}$ channels and that this is important for neurotransmitter release (Augustine and Neher, 1992). These highly localized increases of $\left[\mathrm{Ca}^{2+}\right]_{i}$ are not detectable by standard methods of $\left[\mathrm{Ca}^{2+}\right]_{i}$ measurement such as those used here and may be only roughly reflected in measurements of global $\left[\mathrm{Ca}^{2+}\right]_{i}$. Second, the relationship between survival and $\left[\mathrm{Ca}^{2+}\right]_{i}$ may be a threshold effect with no PCD suppression occurring until the requircd concentration is attained. Once this concentration is exceeded, survival is promoted in a nearly all-or-none manner. If a threshold of $\left[\mathrm{Ca}^{2+}\right]_{i}$ is required to promote survival, the lack of significant difference in $\left[\mathrm{Ca}^{2+}\right]_{i}$ that promote widely different levels of survival may be explained, at least in part, by experimental error. That is, if very small increases in $\left[\mathrm{Ca}^{2+}\right]_{i}$ (at the threshold) make the difference in all cells living or dying the technique used here might not be able to accurately distinguish these differences due to "noise" in the measurement process.

The role of $L$-type $C a^{2+}$ channels in depolarization-induced rise of $\left[\mathrm{Ca}^{2+}\right]_{\mathrm{i}}$ and suppression of $\mathrm{PCD}$

Almost $90 \%$ of the sustained increase of steady-state $\left[\mathrm{Ca}^{2+}\right]_{i}$ and $100 \%$ of the survival enhancement caused by chronic depolarization were blocked in a dose-dependent manner by the DHP 
$\mathrm{Ca}^{2+}$ channel antagonist nifedipine. These data strongly suggest that $\mathrm{Ca}^{2+}$ current carried by L-type $\mathrm{Ca}^{2+}$ channels was responsible for the increased $\left[\mathrm{Ca}^{2+}\right]_{i}$ and enhanced survival. The N-type channel antagonist $\omega$-conotoxin, which has no effect on L-channels in rat SCG neurons (Plummer et al., 1989), also had no effect on steady-state $\left[\mathrm{Ca}^{2+}\right]_{i}$ in depolarized cells or on survival of depolarized, NGF-deprived neurons. The lack of complete block of the sustained rise of $\left[\mathrm{Ca}^{2+}\right]_{i}$ by a DHP antagonist might be because of $\mathrm{Ca}^{2+}$ influx through channels other than L-type or $\mathrm{N}$-type or because of failure of $\mathrm{L}$-channel antagonists to completely block the activity of L-channels even at saturating concentrations. Therefore, most, or all, of the $\left[\mathrm{Ca}^{2+}\right]_{i}$ increase in chronically depolarized rat SCG neurons is probably caused by $\mathrm{Ca}^{2+}$ influx through L-type channels. This finding is rather surprising since $\approx 85-90 \%$ of the whole-cell $\mathrm{Ca}^{2}$ current in the soma of these cells is carried by N-type channels, most of which are sensitive to block by $\omega$-conotoxin (Plummer et al., 1989; Regan et al., 1991). Moreover, N-type channels in rat SCG neurons have a noninactivating or slowly inactivating component that lasts for at least several hundred $\mathrm{ms}$ during sustained depolarizations to some of the $V_{m}$ values examined in this article. Such a noninactivating component would, seemingly, contribute to prolonged increases of $\left[\mathrm{Ca}^{2+}\right]_{i}$ in chronically depolarized cells. Since $\omega$-conotoxin-sensitive channels were clearly not involved in the depolarization-induced increase of $\left[\mathrm{Ca}^{2+}\right]_{i}$ and survival reported here, it seems likely that during longer depolarizations these channels do undergo steady-state inactivation.

Although the whole-cell and single-channel $\mathrm{Ca}^{2+}$ currents of rat SCG neurons have been studied in considerable detail (Belluzzi and Sacchi, 1989; Nerbonne and Gurney, 1989; Plummer et al., 1989; Regan et al., 1991), an in-depth analysis of pharmacologically separated L-type and N-type whole-cell $\mathrm{Ca}^{2+}$ currents in these cells has not yet been done. The most likely explanation for how L-channels may cause a sustained elevation of $\left[\mathrm{Ca}^{2+}\right]_{i}$ is that there is a range of $V_{m}$ values in which the activation and inactivation curves of the channels cross resulting in a continuously active $\mathrm{Ca}^{2+}$ "window" current. It will be of interest to characterize more completely the L-type currents in these cells and correlate their properties with the effects of different $V_{m}$ values on survival and $\left[\mathrm{Ca}^{2+}\right]_{i}$. Because the prolonged depolarizations caused by elevated $\left[\mathrm{K}^{+}\right]_{c}$ are unlikely to occur in vivo, determination of the effects of more physiological electrical activity on $\left[\mathrm{Ca}^{2+}\right]_{i}$ and survival will also be interesting. Perhaps with more natural forms of stimulation, $\mathrm{Ca}^{2+}$ influx through N-type channels can also contribute to survival.

\section{How does $\mathrm{Ca}^{2+}$ influx prevent $\mathrm{PCD}$ ?}

Elevated $\left[\mathrm{K}^{+}\right]$。 could conceivably promote survival of NGFdeprived rat SCG in culture by stimulating a $\mathrm{Ca}^{2+}$-dependent release of autocrine or paracrine factors. About $9 \%$ of the cells in these cultures were non-neuronal (about 100-200/dish). These cells did not show any particular association with neurons, appearing to be randomly distributed in the dish. Since the cultures were maintained in as much as $2 \mathrm{ml}$ of medium, the large dilution factor indicates that high- $\left[\mathrm{K}^{+}\right]_{o}$ promoted survival cannot be caused by release of paracrine factors by non-neuronal cells. Acheson et al. (1987) reached similar conclusions concerning the effects of high $\left[\mathrm{K}^{+}\right]_{o}$ on survival of embryonic chicken DRG neurons in culture. We have found that the plating density of neurons in culture does not affect the ability of depolarization to enhance survival. Superior cervical ganglion neurons in low-density cultures deprived of NGF and supported by high $\left[\mathrm{K}^{+}\right]_{o}$ had about the same percentage of control survival as those in high-density cultures (10-fold differences in density; data not shown). If a factor were released by the neurons, more should be available in high-density cultures and survival would, presumably, be enhanced via both autocrine and paracrine effects. However, highly localized paracrine or autocrine effects, (for example, synaptic release) in low-density cultures are possible. Recent work suggests that brain-derived neurotrophic factor (BDNF) is, at least partially, responsible for depolarizationenhanced survival of cortical neurons in culture (Ghosh et al., 1994). We have found that BDNF has no effect on the survival of NGF-deprived SCG neurons (unpublished observation) making it unlikely that BDNF release is the mechanism by which depolarization promotes survival of these cells. NGF cannot be a survival factor released by depolarized SCG neurons since the anti-NGF antibody in the culture medium neutralizes its effects and Trk was not activated. Additionally, since the antibody used for Trk immunoprecipitation recognizes all members of the Trk receptor family in rodents (TrkA, TrkB, TrkC; Zhou et al., 1994), none of the other members of the neurotrophin family were released in depolarized neurons. Therefore, depolarization-induced release of neurotrophins is not the mechanism by which depolarization suppresses PCD. Ciliary neurotrophic factor (CNTF) and leukemia inhibitory factor (LIF) have both survival- and death-promoting effects on these cells, saving some populations of neurons while killing others (Kessler et al., 1994; Kotzbauer et al., 1994). Depolarization prevented death of all cells deprived of NGF, thus probably eliminating CNTF and LIF as autocrine factors. A number of bioactive peptides, which might possibly act as autocrine factors, do not cnhance survival of these cells in the absence of NGF (Martin et al., 1992). The effect of depolarization on Trk tyrosine kinase activity was investigated over only a $15 \mathrm{~min}$ period in this report. The data clearly indicated that there is no short-term activation of Trk by depolarization. However, the data do not rule out long-term effects such as those reported by Ghosh et al., 1994. We are actively investigating the possibility that other members of the neurotrophin family and, perhaps, their receptors may be upregulated in chronically depolarized neurons and act as autocrine or paracrine factors mediating the effects of depolarization on survival.

One possible explanation for the relationship between $\left[\mathrm{Ca}^{2+}\right]_{i}$ and survival illustrated in Figure 10 is that $\mathrm{Ca}^{2+}$-binding protein(s) mediating effects of increased $\left[\mathrm{Ca}^{2+}\right]_{i}$ on survival bind $\mathrm{Ca}^{2+}$ cooperatively. Such cooperative binding can result in "switch-like" concentration-response relationships. Therefore, rather than a graded concentration-response relationship between survival and $\left[\mathrm{Ca}^{2+}\right]_{i}$ such a mechanism would show survival increasing only when a threshold level of $\left[\mathrm{Ca}^{2+}\right]_{i}$ is exceeded. The best-characterized protein exhibiting this type of binding is calmodulin, a ubiquitous and abundant $\mathrm{Ca}^{2+}$-binding protein found in all eukaryotic cells (Cohen and Klee, 1988; Rasmussen and Means, 1989; Heinzmann, 1991). In mammals calmodulin has three or four cooperative $\mathrm{Ca}^{2+}$-binding sites. This $\mathrm{Ca}^{2+}$-binding characteristic causes calmodulin to act as a $\mathrm{Ca}^{2+}$-concentration threshold detector, not activating until all sites are bound and then activating in a near all-or-none manner. Gallo et al. (1987) show that high $\left[\mathrm{K}^{+}\right]_{o}$-induced survival of rat cerebellar granule cells in culture is blocked by the calmodulin antagonists, trifluoperazine and calmidazolium, suggesting that calmodulin activation may mediate the effect. In light of our 
finding that calmodulin antagonists, including calmidazolium, apparently block survival of chronically depolarized NGF-deprived rat SCG neurons by blocking $\mathrm{Ca}^{2+}$ influx, a similar block likely occurs in granule cells and, thus, a role for calmodulin in depolarization-enhanced survival of those cells remains an open question. Calmidazolium did not effect a sustained increase of $\left[\mathrm{Ca}^{2+}\right]_{i}$ induced by thapsigargin and elevated $\left[\mathrm{Ca}^{2+}\right]_{0}$ in rat $\mathrm{SCG}$ neurons. However, calmidazolium was toxic to control cells and cells "saved" from PCD by the thapsigargin/high $\left[\mathrm{Ca}^{2+}\right]_{i}$ treatment at similar concentrations. Whether the effects of the calmodulin antagonists on survival of control cells resulted from inhibition of calmodulin or nonspecific toxic effects, we did not determine. Thus, because of the nonspecificity of calmodulin antagonists we were not able to verify or refute a role for calmodulin activation in $\mathrm{Ca}^{2+}$-increased survival of these cells.

Significant activation of the Trk tyrosine kinase occurred only with NGF treatment; depolarization had little effect. Thus, activation of Trk by increased $\left[\mathrm{Ca}^{2+}\right]_{i}$ probably does not occur and is not the mechanism by which depolarization promotes survival. The increased tyrosine phosphorylation of a protein with a molecular weight of about $44 \mathrm{kDa}$ by both NGF and depolarization is intriguing since this is the approximate molecular weight of ERKs (Boulton et al., 1991; Cobb et al., 1991; Davis, 1993). Increased tyrosine phosphorylation of these kinases is caused not only by growth factor treatment but many other stimuli as well, including $\mathrm{KCl}$ in PC12 cells (Tsao et al., 1990) and in the brain by electroconvulsive shock (Stratton et al., 1991). ERKs are activated by phosphorylation on tyrosine and threonine/serine residues. When activated, ERKs phosphorylate a large number of substrates including other kinases, microtubule-associated proteins, and transcription factors. Many of the effects of growth factors are thought to be mediated by these phosphorylations. ERKs can be activated by several other kinases involved in growth-factor signaling including Raf-1 kinase. Raf-1 can be activated either by protein kinase C (PKC; Kolch et al., 1993) or by a PKC-independent receptor tyrosine kinase pathway. Protein kinase $\mathrm{C}$ has $\mathrm{Ca}^{2+}$-dependent forms and is also activated by diacyl glycerol (DAG) (Huang, 1989). PKC may be involved in depolarization-enhanced survival of chicken sympathetic neurons in culture (Wakade et al., 1988). In these cells chronic depolarization increases PKC activity, and phorbol esters, which mimic the action of DAG on PKC, will substitute for depolarization in supporting survival. The PKC activator phorbol 12-myristate 13-acetate (PMA) has no effect on survival of NGF-deprived rat SCG neurons at concentrations that promote survival of chicken neurons (Martin et al., 1992). However, this type of experiment is difficult to interpret since PMA causes profound down regulation of $\mathrm{PKC}$ in rat SCG neurons (Matthies et al., 1987). If $\mathrm{Ca}^{2+}$ prevents $\mathrm{PCD}$ through activation of a PKC-dependent pathway, phorbol ester treatment of depolarized, NGF-deprived neurons might downregulate PKC and block survival. However, we have found that the ability of $50 \mathrm{~K}$ to promote survival of rat SCG neurons deprived of NGF is not affected by PMA treatment (unpublished observation). Thus, PMA has no effect on survival of rat SCG neurons under any condition. It appears, therefore, that $\mathrm{PKC}$ is not involved in depolarization-enhanced survival of rat SCG neurons. Further investigation of potential roles for ERKs, calmodulin, and additional $\mathrm{Ca}^{2+}$-binding proteins in depolarization-induced survival of these cells is beyond the scope of this report and will be pursued in future work.

\section{Separation of growth and survival}

Onc of the most interesting results reported here is that NGF promotes both growth and survival of SCG neurons while chronic depolarization supports survival but little growth. This finding suggests that growth and survival are mediated via separate signal transduction pathways. Neurites of NGF-deprived neurons were stabilized by elevated $\left[\mathrm{K}^{+}\right]_{0}$ with only a little growth and retraction occurring. This finding is similar to results reported recently by Teng and Greene (1993) in PC1 2 cells. When PC1 2 cells are exposed to NGF, they extend neurites and differentiate into a phenotype resembling that of sympathetic neurons. After differentiation, removal of NGF causes neurites to degenerate and the cells revert to a phenotype similar to the one they had before exposure to NGF. When Teng and Greene depolarized differentiated PC1 2 cells with elevated $\left[\mathrm{K}^{+}\right]_{o}$, NGF removal did not cause neurite degeneration. Instead, neurites were stabilized; little extension or retraction occurred. This stabilization is blocked by DHP $\mathrm{Ca}^{2+}$ channel antagonists suggesting that the effect of chronic depolarization is mediated by $\mathrm{Ca}^{2+}$ influx through L-type channels. The stabilizing effect of high $\left[\mathrm{K}^{+}\right]_{o}$ on PC12 cell neurites is suggested to be a result of stabilization of the cytoskeleton caused, perhaps, by $\mathrm{Ca}^{2+}-\mathrm{ac}-$ tivated phosphorylation of cytoskeletal proteins. This hypothesis is supported by the work of Riederer et al. (1992) showing that sustained depolarization of fetal rat telencephalic neurons in culture enhances development and maturation of their cytoskeleton. It is likely that the stabilization of neurites in NGFdeprived SCG neurons by elevated $\left[\mathrm{K}^{+}\right]_{o}$ is the same phenomenon observed in $\mathrm{PCl} 2$ cells exposed to high $\left[\mathrm{K}^{+}\right]_{0}$. If the cytoskeletal stabilization hypothesis is correct it is possible that such stabilization may also be, at least partially, responsible for depolarization-enhanced survival.

In summary, the data presented here indicate that, while chronic depolarization prevented PCD of NGF-deprived rat sympathetic neurons in culture by causing a DHP-sensitive $\mathrm{Ca}^{2+}$ influx, the relationship between increased $\left[\mathrm{Ca}^{2+}\right]_{i}$ and survival was not clear-cut. This finding suggests that the connection between $\left[\mathrm{Ca}^{2+}\right]_{i}$ and survival may be more complex than previously assumed, perhaps involving localized $\mathrm{Ca}^{2+}$ pools or $\left[\mathrm{Ca}^{2+}\right]_{i}$ thresholds. Little growth was supported by chronic depolarization in the absence of NGF. The NGF receptor, Trk, was probably not involved in mediating the effect of depolarization on survival and the non-specificity of calmodulin antagonists did not allow investigation of a role for calmodulin. $A \approx 44 \mathrm{kDa}$ protein that may be an ERK became phosphorylated on tyrosine residues in response to both NGF and depolarization indicating that this protein is a point of convergence for depolarization and NGF signaling pathways. This protein and its potential role in transduction of growth factor and $\mathrm{Ca}^{2+}$-promoted survival should be most interesting to characterize. Synergistic effccts of growth factors and depolarization on survival have been recently demonstrated in embryonic chicken ciliary ganglion neurons in culture (Schmidt and Kater, 1993). Such synergism might be caused by activation of the same signaling pathways. This is an appealing idea since convergence of depolarization and neurotrophic signals on the same pathways is a parsimonious and relatively simple means by which afferent input to a neuron (e.g., electrical activity/release of factors from presynaptic cells) and target-derived influences (growth factors) could combine to determine which neurons are spared from PCD. 


\section{References}

Acheson A, Barde Y-A, Thoenen H (1987) $\mathrm{High} \mathrm{K}^{+}$-mediated survival of spinal sensory neurons depends on developmental stage. Exp Cell Res 170:56-63.

Augustine GJ, Neher E (1992) Neuronal $\mathrm{Ca}^{2+}$ signalling takes the local route. Curr Opinion Neurobiol 2:302-307.

Belluzzi O, Sacchi O (1989) Calcium currents in the normal adult rat sympathetic neurone. J Physiol (Lond) 412:493-512.

Boulton TG, Nye SH, Robbins DJ, Ip NY, Radziejewska E, Morgenbesser SD, DePinho RA, Panayotatos N, Cobb MH, Yancopoulos GD (1991) Erks: a family of protein-serine/threonine kinases that are activated and tyrosine phosphorylated in response to insulin and NGF. Cell 65:663-675.

Campenot RB (1986) Retraction and degencration of sympathetic neurites in response to locally elevated potassium. Brain Res 399: 357-363.

Catsicas M, Péquignot Y, Clarke PGH (1992) Rapid onset of neuronal death induced by blockade of either axoplasmic transport or action potentials in afferent fibers during brain development. J Neurosci 12: $4642-4650$.

Chalazonitis A, Fischbach GD (1980) Elevated potassium induces morphological differentiation of dorsal root ganglionic neurons in dissociated cell culture. Dev Biol 78:172-183.

Cobb MH, Boulton TG, Robbins DJ (1991) Extracellular signal-regulated kinases: ERKs in progress. Cell Regul 2:965-978.

Cohen P, Klee CB (1988) Calmodulin. New York: Elsevier.

Collins F, Lile JD (1989) The role of dihydropyridine-sensitive voltage-gated calcium channels in potassium-mediated neuronal survival. Brain Res 502:99-108.

Collins F, Schmidt MF, Guthrie PB, Kater SB (1991) Sustained increase in intracellular calcium promotes neuronal survival. $J$ Neurosci 11:2582-2587.

Davis RJ (1993) The mitogen-activated protein kinase signal transduction pathway. J Biol Chem 268:14553-14555.

Deckwerth TL, Johnson EM Jr (1993) Temporal analysis of events associated with programmed cell death (apoptosis) of sympathetic neurons deprived of nerve growth factor. J Cell Biol 123:1207-1222.

Doroshenko PA, Kostyuk PG, Luk'yanetz EA (1988) Modulation of calcium currents by calmodulin antagonists. Neuroscience 27:10731080.

Duvall E, Wyllie AH (1986) Death and the cell. Immunol Today 7:115-119.

Edwards SN, Buckmaster AE, Tolkovsky AM (1991) The death programme in cultured sympathetic neurones can be suppressed at thc posttranslational level by nerve growth factor, cyclic AMP, and depolarization. J Neurochem 57:2140-2143.

Eichler ME, Dubinsky JM, Rich KM (1992) Relationship of intracellular calcium to dependence on nerve growth factor in dorsal root ganglion neurons in cell culture. J Neurochem 58:263-269.

Fox AP, Nowycky MC, Tsien RW (1987) Kinetic and pharmacological properties distinguishing three types of calcium currents in chick sensory neurones. J Physiol (Lond) 394:149-172.

Franklin JL, Johnson EM Jr (1992) Suppression of programmed neuronal death by sustained elevation of cytoplasmic calcium. Trends Neurosci 15:501-508.

Franklin JL, Juhasz A, Cornbrooks EB, Lampe PA, Johnson EM Jr (1992) Promotion of sympathetic neuronal survival by chronic depolarization and increased $\left[\mathrm{Ca}^{2+}\right]_{i}$ is a threshold phenomenon. Soc Neurosci Abstr 18:30.4.

Franklin JL, Sanz-Rodriguez C, Juhasz A, Johnson FM Jr (1993) Differential effects of NGF and chronic depolarization on the survival and neurite outgrowth of sympathetic neurons in culture. Soc Neurosci Abstr 19:187.13.

Furber S, Oppenheim RW, Prevette D (1987) Naturally-occurring neuron death in the ciliary ganglion of the chick embryo following removal of preganglionic input: evidence for the role of afferents in ganglion cell survival. J Neurosci 7:1816-1832.

Galli-Resta L, Ensini M, Fusco E, Gravina A, Margheritti B (1993) Afferent spontaneous electrical activity promotes the survival of target cells in the developing retinotectal system of the rat. J Neurosci 13: 243-250.

Gallo V, Kingsbury A, Balázs R, Jørgensen OS (1987) The role of depolarization in the survival and differentiation of cerebellar granule cells in culture. J Neurosci 7:2203-2213.

Ghosh A, Carnahan J, Greenberg ME (1994) Requirement for BDNF in activity-dependent survival of cortical neurons. Science 263:16181623.

Goldman DE (1943) Potential, impedance, and rectification in membranes. J Gen Physiol 27:37-60.

Gray WR, Olivera BM, Cruz LJ (1988) Peptide toxins from venomous Conus snails. Annu Rev Biochem 57:665-700.

Greenberg DA, Carpenter CL, Messing RO (1987) Interaction of calmodulin inhibitors and protein kinase $C$ inhibitors with voltage-dependent calcium channels. Brain Res 404:401-404.

Grynkiewicz G, Poenie M, Tsien RY (1985) A new generation of $\mathrm{Ca}^{2+}$ indicators with greatly improved fluorescence properties. J Biol Chem 260:3440-3450.

Hamill OP, Marty A, Neher E, Sakman B, Sigworth FJ (1981) Improved patch-clamp techniques for high-resolution current recording from cells and cell-free membrane patches. Pfluegers Arch 391:85100.

Heinzmann CW (1991) Novel calcium binding proteins: Fundamentals and clinical implications. New York: Springer-Verlag.

Hille B (1992) Ionic channels of excitable membranes. Sunderland, MA: Sinauer.

Hodgkin AL, Katz B (1949) The effect of sodium ions on the electrical activity of the giant axon of the squid. J Physiol (Lond) 108:37-77.

Hoth M. Penner R (1992) Depletion of intracellular calcium stores activates a calcium current in mast cells. Nature 355:353-356.

Huang K-P (1989) The mechanism of protein kinase C activation. Trends Neurosci 12:425-432.

Jan LY, Jan YN (1976) L-Glutamate as an excitatory transmitter at the Drosophila larval neuromuscular junction. J Physiol (Lond) 262: 215-236.

Johnson EM Jr, Koike T, Franklin J (1992) A "calcium set-point hypothesis" of neuronal dependence on neurotrophic factor. Exp Neurol 115:163-166.

Johnson MI, Argiro V (1983) Techniques in the tissue culture of rat sympathetic neurons. Methods Enzymol 103:334-347.

Kaplan DR, Hempstead BL, Martin-Zanca D, Chao MV, Parada LF (1991) The trk proto-oncogene product: a signal transducing receptor for nerve growth factor. Science 252:554-558.

Kessler JA, Ludlam WH, Friedin MM, Hall DH, Michaelson MD, Spray DC, Dougherty M, Batter DK (1993) Cytokine induced programmed death of cultured sympathetic neurons. Neuron 11:11231132.

Kolch W, Heidecker G, Kochs G, Hummel R, Vahidi H, Mischak H, Finkenzeller G, Marmé D, Rapp UR (1993) Protein kinase C $\alpha$ activates Raf- 1 by direct phosphorylation. Nature 364:249-252.

Koike T, Tanaka S (1991) Evidence that nerve growth factor dependence of sympathetic neurons for survival in vitro may be determined by levels of cytoplasmic free $\mathrm{Ca}^{2+}$. Proc Natl Acad Sci USA 88:38923896.

Koike T, Martin DP, Johnson EM Jr (1989) Role of $\mathrm{Ca}^{2+}$ channels in the ability of membrane depolarization to prevent neuronal death induced by trophic-factor deprivation: evidence that levels of internal $\mathrm{Ca}^{2+}$ determine nerve growth factor dependence of sympathetic ganglion cells. Proc Natl Acad Sci USA 86:6421-6425.

Kotzbauer PT, Lampe PA, Estus S, Millbrandt J, Johnson EM Jr (1994) Postnatal development of survival responsiveness in rat sympathetic neurons to leukemia inhibitory factor and ciliary neurotrophic factor. Neuron 12:763-773.

Lampe PA, Cornbrooks EB, Juhasz A, Franklin JL, Johnson EM Jr (1992) Thapsigargin enhances survival of sympathetic neurons by elevating intracellular calcium concentration $\left(\left[\mathrm{Ca}^{2+}\right]_{i}\right)$. Soc Neurosci Abstr 18:30.5.

I azarus KJ, Bradshaw RA, West NR, Bunge RP (1976) Adaptive survival of rat sympathetic neurons cultured without supporting cells or exogenous nerve growth factor. Brain Res 113:159-164.

Lipton SA (1986) Blockade of electrical activity promotes the death of mammalian retinal ganglion cells in culture. Proc Natl Acad Sci USA 83:9774-9778.

Lückhoff A, Clapham DE (1992) Inositol 1,3,4,5-tetrakisphosphate activates an endothelial $\mathrm{Ca}^{2+}$-permeable channel. Nature 355:356358.

Maderdrut JL, Oppenheim RW, Prevette D (1988) Enhancement of 
naturally occurring cell death in the sympathetic and parasympathetic ganglia of the chicken embryo following blockade of ganglionic transmission. Brain Res 444:189-194.

Martin DP, Schmidt RE, DiStefano PS, Lowry OH, Carter JG, Johnson EM Jr (1988) Inhibitors of protein synthesis and RNA synthesis prevent neuronal death caused by nerve growth factor deprivation. $J$ Cell Biol 106:829-844.

Martin DP, Ito A, Horigome K, Lampe PA, Johnson EM Jr (1992) Biochemical characterization of programmed cell death in NGF-deprived sympathetic neurons. J Neurobiol 23:1205-1220.

Matthies HJG, Palfrey HC, Hirning LD, Miller RJ (1987) Down regulation of protcin kinasc $C$ in ncuronal cclls: cffects on neurotransmitter release. J Neurosci 7:1198-1206.

McClesky EW, Fox AP, Feldman DH, Cruz LJ, Olivera BM, Tsien RW, Yoshikami D (1987) $\omega$-Conotoxin: direct and persistent blockade of specific types of calcium channels in neurons but not muscle. Proc Natl Acad Sci USA 84:4327-4331.

McCormack JG, Cobbold PH (1991) Cellular calcium: a practical approach. Oxford: Oxford UP.

Mosman T (1983) Rapid colorimetric assay for cellular growth and survival: application to proliferation and cytotoxicity assays. J Immunol Methods 65:55-63.

Nerbonne JM, Gurney AM (1989) Development of excitable membrane properties in mammalian sympathetic neurons. J Neurosci 9:3272-3286.

Nishi R, Berg DK (1981) Effects of high $\mathrm{K}^{+}$concentrations on the growth and development of ciliary ganglion neurons in cell culture. Dev Biol 87:301-307.

Olivera BM, Rivier J, Scott JK, Hillyard DR, Cruz LJ (1991) Conotoxins. J Biol Chem 266:22067-22070.

Oppenheim RW (1991) Cell death during development of the nervous system. Annu Rev Neurosci 14:453-501.

Pasic TR, Rubel EW (1989) Rapid changes in cochlear nucleus cell size following blockade of auditory nerve electrical activity in gerbils. J Comp Neurol 283:474-480.

Plummer MR, Logethetis DE, Hess P (1989) Elementary properties and pharmacological sensitivities of calcium channels in mammalian peripheral neurons. Neuron 2:1453-1463.

Porzig H (1990) Pharmacological modulation of voltage-dependent calcium channcls in intact cells. Rev Physiol Biochem Pharmacol 114:209-262.

Putney JW, Bird GSJ (1993) The signal for capacitive calcium entry. Cell 75:199-201.

Rasmussen CD, Means AR (1989) Calmodulin, cell growth and gene expression. Trends Neurosci 12:433-438.

Regan LJ, Sah DWY, Bean BP (1991) $\mathrm{Ca}^{2+}$ channels in rat central and peripheral neurons: high-threshold current resistant to dihydropyridine blockers and $\omega$-conotoxin. Neuron 6:269-280.
Riederer BM, Monnet-Tschudi F, Honegger P (1992) Development and maintenance of the neuronal cytoskeleton in aggregated cell cultures of fetal rat telencephalon and influence of elevated $\mathrm{K}^{+}$concentrations. J Neurochem 58:649-658.

Ruitjer JM, Baker RE, De Jong BM, Romijn HJ (1991) Chronic blockade of bioelectric activity in neonatal rat cortex grown in vitro. Morphological effects. Int J Dev Neurosci 9:331-338.

Schlessinger J, Ulirich A (1992) Growth factor signalling by receptor tyrosine kinases. Neuron 9:383-391.

Schmidt MF, Kater SB (1993) Fibroblast growth factors, depolarization, and substratum interact in a combinatorial way to promote ncuronal survival. Dev Biol 158:228-237.

Scott BS (1971) Effect of potassium on neuron survival in cultures of dissociated human nervous tissue. Exp Neurol 27:297-308.

Scott BS, Fisher KC (1970) Potassium concentration and number of neurons in cultures of dissociated ganglia. Exp Neurol 27:16-22.

Sher E, Clementi F (1991) $\omega$-Conotoxin-sensitive voltage-operated calcium channels in vertebrate cells. Neuroscience 42:301-307.

Stratton KR, Worley PF, Litz JS, Parsons SJ, Huganir RL, Baraban JM (1991) Electroconvulsive treatment induces a rapid and transient increase in tyrosine phosphorylation of a 40 -kilodalton protein associated with microtubule-associated protein 2 kinase activity. J Neurochem 56:147-152.

Teng KK, Greene LA (1993) Depolarization maintains neurites and priming of $\mathrm{PCl} 2$ cells after nerve growth factor withdrawal. J Neurosci 13:3124-3135.

Thayer SA, Hirning LD, Miller RJ (1987) Distribution of multiple types of $\mathrm{Ca}^{2+}$ channels in rat sympathetic neurons in vitro. Mol Pharmacol 32:579-586.

Tolkovsky AM, Walker AE, Murrell RD, Suidan HS (1990) $\mathrm{Ca}^{2+}$ transients are not required as signals for long-term neurite outgrowth from cultured sympathetic neurons. J Cell Biol 110:1295-1306.

Triggle DJ (1990) Calcium, calcium channels, and calcium channel antagonists. Can J Physiol Pharmacol 68:1474-1481.

Tsao H, Aletta JM, Greene LA (1990) Nerve growth factor and fibroblast growth factor selectively activate a protein kinase that phosphorylates high molecular weight microtubule-associated proteins. $J$ Biol Chem 265:15471-15480.

Wakade AR, Wakade TD, Malhotra RK, Bhave SV (1988) Excess K+ and phorbol ester activate protein kinase $C$ and support the survival of chick sympathetic neurons in culture. J Neurochem 51:975-983.

Zhou J, Holtzman DM, Weiner RI, Mobley WC (1994) Expression of TrkA confers neuronlike responsiveness to nerve growth factor on an immortalized hypothalamic cell line. Proc Natl Acad Sci USA 91: $3824-3828$ 